Review

\title{
Effect of Metals, Metalloids and Metallic Nanoparticles on Microalgae Growth and Industrial Product Biosynthesis: A Review
}

\section{Krystian Miazek ${ }^{1, *}$, Waldemar Iwanek ${ }^{2}$, Claire Remacle ${ }^{3}$, Aurore Richel ${ }^{4}$ and Dorothee Goffin 5}

1 AgricultureIsLife Platform, University of Liege-Gembloux Agro-Bio Tech, Passage des Déportés 2, Gembloux B-5030, Belgium

2 Faculty of Mathematics and Natural Sciences, the Jan Kochanowski University in Kielce, Swietokrzyska 15, Kielce 25-406, Poland; E-Mail: iwanek@pu.kielce.pl

3 Genetics and Physiology of Microalgae, Institute of Botany, University of Liege, B22, 27, Bld du Rectorat, Liège B-4000, Belgium; E-Mail: c.remacle@ulg.ac.be

4 Unit of Biological and Industrial Chemistry, University of Liege-Gembloux Agro-Bio Tech, Passage des Déportés 2, Gembloux B-5030, Belgium; E-Mail: a.richel@ulg.ac.be

5 Cellule Innovation et Créativité, University of Liege-Gembloux Agro-Bio Tech, Passage des Déportés 2, Gembloux B-5030, Belgium; E-Mail: dorothee.goffin@ulg.ac.be

* Author to whom correspondence should be addressed; E-Mail: kmiazek@ulg.ac.be; Tel.: +48-60-817-8511.

Academic Editor: Christopher Q. Lan

Received: 18 August 2015 / Accepted: 24 September 2015 / Published: 9 October 2015

\begin{abstract}
Microalgae are a source of numerous compounds that can be used in many branches of industry. Synthesis of such compounds in microalgal cells can be amplified under stress conditions. Exposure to various metals can be one of methods applied to induce cell stress and synthesis of target products in microalgae cultures. In this review, the potential of producing diverse biocompounds (pigments, lipids, exopolymers, peptides, phytohormones, arsenoorganics, nanoparticles) from microalgae cultures upon exposure to various metals, is evaluated. Additionally, different methods to alter microalgae response towards metals and metal stress are described. Finally, possibilities to sustain high growth rates and productivity of microalgal cultures in the presence of metals are discussed.
\end{abstract}


Keywords: microalgae; metal stress; industrial products; growth rate; metal resistance

\section{Introduction}

Microalgae are photosynthetic microorganisms, using solar light to convert $\mathrm{CO}_{2}$ from the atmosphere into organic carbon. There are eukaryotic microalgae such as green microalgae [1], red microalgae [2], diatoms [3] and dinoflagellates [4] or prokaryotic cyanobacteria [5]. Some of them are capable of growing mixotrophically or heterotrophically because they use sugars, glycerol or organic acids as their carbon source [6]. The optimal temperature for microalgae growth is usually $20-30{ }^{\circ} \mathrm{C}$, but it is also reported that some strains are able to grow at much lower [7] or higher [8] temperature conditions. Microalgae are a source of valuable compounds such as lipids, pigments, carbohydrates, vitamins, and proteins, with potential applications in many branches of industry. Nowadays, research is focused on improving synthesis and maximizing production of valuable compounds from microalgae cultures. Microalgal cells are able to synthetize numerous compounds in higher amounts, as a response to stress conditions such as high temperature, high salinity, nutrient starvation, and also metal stress. However, stress conditions can also have negative effects on microalgae growth $[9,10]$.

Human activity, development of industry and natural Earth processess lead to release of numerous metals (Fe, $\mathrm{Zn}, \mathrm{Cu}, \mathrm{Cd}, \mathrm{Cr}, \mathrm{Ni}, \mathrm{Hg}, \mathrm{Pb}, \mathrm{La}, \mathrm{Li}, \mathrm{V}$ ), metalloids (As, Te) and metallic nanoparticles $\left(\mathrm{Ag}, \mathrm{Pt}, \mathrm{TiO}_{2}, \mathrm{ZnO}, \mathrm{CeO}_{2}, \mathrm{NiO}, \mathrm{BaTiO}_{3}, \mathrm{Y}_{2} \mathrm{O}_{3}, \mathrm{Al}_{2} \mathrm{O}_{3}\right)$ [11-16] that can act as stressors or modulators for microalgae growth and metabolism. This review presents advantages and disadvantages of metal stress, as a possible method to produce industrial compounds from microalgae cultures.

\section{Effect of Metals on Microalgae: Growth Inhibition vs. Growth Enhancement}

Metals at small concentrations are indispensable for microalgae cells to perform cellular functions. They act as components for photosynthetic electron transport proteins $(\mathrm{Cu}, \mathrm{Fe})$ and photosynthetic water oxidizing centres ( $\mathrm{Mn})$ or are constituents of vitamins (Co) [17]. They also serve as cofactors for enzymes participating in $\mathrm{CO}_{2}$ fixation ( $\mathrm{Zn}$ in carbonic anhydrase) [18], DNA transcription (Zn in RNA polymerase) and phosphorus acquisition ( $\mathrm{Zn}$ in alkaline phosphatase) [19] or $\mathrm{N}_{2}$ assimilation (Mo, Fe, $\mathrm{V}$ in nitrogenase) [20] and nitrate reduction (Mo in nitrate and Fe in nitrite reductase) [21]. However, high concentrations of these metals, and other non-essential heavy metals ( $\mathrm{Hg}, \mathrm{As}, \mathrm{Cd}, \mathrm{Pb}, \mathrm{Cr}$ ) cause negative effects (impairment of photosynthetic mechanism, blockage of cell division, inhibition of enzyme activity) in microalgae cells [12]. Metals also influence the morphology of microalgal cells. Accumulation of cadmium (Cd) in Chlamydomonas acidophila cells resulted in the increase in cell size and decomposition of polyphosphate bodies [22]. The presence of lead $(\mathrm{Pb})$ in Chlorella sorokiniana culture resulted in the formation of colonies of Chlorella cells possessing cytoplasm lipid droplets and misshaped chloroplasts [23]. Fragmentation of thylakoid membranes was observed in Synechocystis sp. cells upon exposure to thallium (Tl) [24]. Mitochondria in Desmidium swartzii cells became enlarged and bloated, upon cell exposure to $\mathrm{Zn}$ [25]. Synergistic effect of aluminum (Al) and lead on Dunaliella tertiolecta caused cell membrane lysis [26]. Cerium (Ce)-associated cell damage in Anabaena flosaquae, can additionally lead to the release of toxins [27]. Lithium (Li) can alter the length and form of flagella 
in Chlamydomonas reinhardtii [28] or affect the structure of polysaccharide sheath around Ankistrodesmus gracilis cells [29], and can also at various concentrations inhibit other microalgae strains [30,31]. Cultivation of diatom Synedra acus in the presence of germanium (Ge), titanium (Ti), zirconium ( $\mathrm{Zr}$ ) or tin ( $\mathrm{Sn}$ ) caused alterations in shape, size and mechanical strength of silica valves in Synedra frustules [32].

Although heavy metals generally have negative effect on microalgae cultures, some reports suggest also their positive role during microalgae cultivation (Table 1). Lead, aluminum [26] and cobalt [33] at low concentrations had stimulatory effect on growth of Dunaliella tertiolecta [26] and Monoraphidium minutum [33]. Arsenic (As(V)) was reported to improve the growth of cyanobacterium Nostoc minutum [34] and microalgae Chlorella salina [35] and Chlorella sp. [36]. What is more, inorganics can support microalgae growth in case of nutrient deficiency. For instance, $20 \mu \mathrm{g} / \mathrm{L}$ vanadium $\left(\mathrm{VO}_{3}{ }^{-}\right)$increased growth of Scenedesmus obliquus grown in iron $\left(\mathrm{Fe}^{3+}\right)$ deficient medium up to six times. Vanadium was almost entirely consumed by Scenedesmus cells under photoautotrophic cultivation conditions [37]. In another study, addition of $0.01-1 \mu \mathrm{g} / \mathrm{L}$ vanadium $\left(\mathrm{VO}_{3}{ }^{-}\right)$resulted in up to $67 \%$ growth enhancement in photoautotrophic Chlorella pyrenoidosa culture, even with iron $\left(\mathrm{Fe}^{3+}\right)$ supplementation in the growth media [38]. However, vanadium $\left(\mathrm{VO}_{3}{ }^{-}\right)$at concentrations above $1 \mathrm{mg} / \mathrm{L}$ was inhibitory for Chlorella pyrenoidosa [38]. Vanadium, in a form of $\mathrm{VO}_{4}{ }^{3-}$ [39] and $\mathrm{V}_{2} \mathrm{O}_{5}$ [40], was also reported to be inhibitory to Haematococcus lacustris [39] and Scenedesmus quadricauda [40].

Furthermore, elements from the lanthanide group such as lanthanum (La), cerium (Ce), neodynium $(\mathrm{Nd})$, europium $(\mathrm{Eu})$ or gadolinium $(\mathrm{Gd})$ were reported to constitute a good replacement for calcium deficiency in Desmodesmus quadricauda culture, with $\mathrm{Gd}$, La or $\mathrm{Nd}$ supplementation leading to nearly the same culture dry weight when compared to Ca supplemented media. Moreover, addition of cerium at low concentration to standard medium increased Desmodesmus cell number in culture. However, lanthanide elements increased growth suppression of Desmodesmus, when added into manganese deficient medium [41]. Also lanthanum at higher concentration inhibited growth of Scenedesmus quadricauda [42] or Sceletonema costatum [43], and inhibitory concentration of La was the same as for other lanthanides: cerium $(\mathrm{Ce})$, neodymium $(\mathrm{Nd})$, samarium $(\mathrm{Sm})$, europium $(\mathrm{Eu})$, gadolinium (Gd), terbium (Tb), dysprosium (Dy), holmium (Ho), erbium (Er), thulium (Tm), ytterbium $(\mathrm{Yb})$ and lutetium $(\mathrm{Lu})$ [43]. Cerium $(\mathrm{Ce})$ was stimulatory at lower concentration and inhibitory at higher concentration towards cyanobacterium Anabaena flosaquae [27].

$\mathrm{Cd}^{2+}$ at small concentrations was reported to stimulate growth and maintain activity of carbonic anhydrase in Thalassiosira weissflogii cells, cultivated in Zn-limited medium [44]. Recently, a novel carbonic anhydrase naturally possesing $\mathrm{Cd}^{2+}$ as a catalytic metal ion, has been discovered in Thalassiosira weissflogii [45].

$\mathrm{Ni}^{2+}$ is an essential metal for cultivation of marine diatoms such as Phaeodactylum tricornutum [46], Cyclotella cryptica [47], Thalassiosira weissflogii and Thalassiosira pseudonana [48], in the presence of urea as a sole nitrogen source. Nickel serves as a cofactor in an enzyme urease, but Ni at higher concentations was inhibitory for diatom growth [47,48]. A lack of Ni can be partially substituted by cobalt [46].

In addition to metals and metalloids, also metallic nanoparticles (NPs) exert activity towards microalgae. Inhibitory effects of $\mathrm{TiO}_{2}, \mathrm{ZnO}, \mathrm{CeO}_{2}, \mathrm{NiO}, \mathrm{BaTiO}_{3}, \mathrm{Y}_{2} \mathrm{O}_{3}, \mathrm{Al}_{2} \mathrm{O}_{3}, \mathrm{Ag}$ and $\mathrm{Pt}$ nanoparticles were reported towards numerous freshwater and marine microalgae strains and their inhibitory 
activity was suggested to be due to Reactive Oxygen Species (ROS) generation [49,50] or mechanical damage caused by nanoparticles themselves [51], but also due to metal ions released from nanoparticles [50,52,53], light shading effect [54], interactions with growth media components [55] or simultaneous effect of various factors [56]. Inhibitory activity of nanoparticles also depends on their size [49] and aged suspension [55] or growth medium composition [53]. On the other hand, metal ions released from nanoparticles can also stimulate growth of cyanobacteria and microalgae [57].

Table 1. Effect of metals, metalloids and metallic nanoparticles on growth of microalgae.

\begin{tabular}{|c|c|c|c|c|c|}
\hline Metal & Microalgae Strain & $\begin{array}{c}\text { Cultivation } \\
\text { Time }\end{array}$ & Concentration & $\begin{array}{l}\text { Effect on } \\
\text { Growth }\end{array}$ & Ref. \\
\hline $\mathrm{Hg}$ & $\begin{array}{c}\text { Chlorella sp. } \\
\text { Scenedesmus acutus }\end{array}$ & 8 days & $2.5-5 \mathrm{mg} / \mathrm{L}$ & $\begin{array}{l}100 \% \text { growth } \\
\text { inhibition }\end{array}$ & {$[58]$} \\
\hline $\mathrm{Hg}$ & Selenastrum capricornutum & - & $0.027 \mathrm{mg} / \mathrm{L}$ & $50 \%$ inhibition & [59] \\
\hline $\mathrm{Pb}$ & Phaeocystis antarctica & 10 days & $0.57 \mathrm{mg} / \mathrm{L}$ & $50 \%$ inhibition & {$[60]$} \\
\hline $\mathrm{Pb}$ & Dunaliella tertiolecta & $\begin{array}{l}48 \mathrm{~h} \\
48 \mathrm{~h}\end{array}$ & $\begin{array}{l}1.5-6.4 \mathrm{mg} / \mathrm{L} \\
7.29 \mathrm{mg} / \mathrm{L}\end{array}$ & $\begin{array}{l}20 \% \text { stimulation } \\
25 \% \text { inhibition }\end{array}$ & {$[26]$} \\
\hline $\mathrm{Cr}(\mathrm{III})$ & $\begin{array}{l}\text { Dyctiosphaerium } \\
\text { chlorelloides }\end{array}$ & $72 \mathrm{~h}$ & $13-17 \mathrm{mg} / \mathrm{L}$ & $50 \%$ inhibition & {$[61]$} \\
\hline $\mathrm{Cr}(\mathrm{III})$ & $\begin{array}{l}\text { Scenedesmus sp. } \\
\text { Geitlerinema sp. }\end{array}$ & $\begin{array}{l}9 \text { days } \\
9 \text { days }\end{array}$ & $\begin{array}{l}0.75 \mu \mathrm{M} \\
0.25 \mu \mathrm{M}\end{array}$ & MMC & {$[62]$} \\
\hline $\mathrm{Cr}(\mathrm{VI})$ & Chlorella pyrenoidosa & $72 \mathrm{~h}$ & $2 \mathrm{mg} / \mathrm{L}$ & $50 \%$ inhibition & {$[63]$} \\
\hline $\mathrm{Cr}(\mathrm{VI})$ & Chlorella vulgaris & $96 \mathrm{~h}$ & $5 \mu \mathrm{mol} / \mathrm{L}$ & $\sim 40 \%$ inhibition & {$[64]$} \\
\hline $\operatorname{As}(\mathrm{III})$ & $\begin{array}{c}\text { Chlorella } \mathrm{sp} . \\
\text { Monoraphidium arcuatum }\end{array}$ & $\begin{array}{l}72 \mathrm{~h} \\
72 \mathrm{~h}\end{array}$ & $\begin{array}{l}25.2 \mathrm{mg} / \mathrm{L} \\
14.6 \mathrm{mg} / \mathrm{L}\end{array}$ & $\begin{array}{l}50 \% \text { inhibition } \\
50 \% \text { inhibition }\end{array}$ & {$[65]$} \\
\hline $\operatorname{As}(\mathrm{III})$ & Chlorella sp. & $72 \mathrm{~h}$ & $27 \mathrm{mg} / \mathrm{L}$ & $50 \%$ inhibition & {$[66]$} \\
\hline $\mathrm{As}(\mathrm{V})$ & Chlorella sp. & $72 \mathrm{~h}$ & $1.1 \mathrm{mg} / \mathrm{L}$ & $50 \%$ inhibition & {$[66]$} \\
\hline $\mathrm{As}(\mathrm{V})$ & $\begin{array}{l}\text { Chlorella } \text { sp. } \\
\text { Monoraphidium arcuatum }\end{array}$ & $\begin{array}{l}72 \mathrm{~h} \\
72 \mathrm{~h}\end{array}$ & $\begin{array}{r}25.4 \mathrm{mg} / \mathrm{L} \\
0.254 \mathrm{mg} / \mathrm{L}\end{array}$ & $\begin{array}{l}50 \% \text { inhibition } \\
50 \% \text { inhibition }\end{array}$ & {$[65]$} \\
\hline $\mathrm{As}(\mathrm{V})$ & $\begin{array}{c}\text { Oscillatoria tenuisa } \\
\text { Anabaena affinis } \\
\text { Microcystis aeruginosa }\end{array}$ & $\begin{array}{l}72 \mathrm{~h} \\
72 \mathrm{~h} \\
72 \mathrm{~h}\end{array}$ & $\begin{array}{l}3.8 \mathrm{mg} / \mathrm{L} \\
2.6 \mathrm{mg} / \mathrm{L} \\
1.2 \mathrm{mg} / \mathrm{L}\end{array}$ & $\begin{array}{l}50 \% \text { inhibition } \\
50 \% \text { inhibition } \\
50 \% \text { inhibition }\end{array}$ & {$[67]$} \\
\hline $\operatorname{As}(\mathrm{III})$ & Nostoc minutum & 7 days & $5 \mathrm{mg} / \mathrm{L}$ & Cell death & {$[34]$} \\
\hline $\mathrm{As}(\mathrm{V})$ & Nostoc minutum & 7 days & $1000 \mathrm{mg} / \mathrm{L}$ & $66 \%$ stimulation & {$[34]$} \\
\hline $\mathrm{Cu}$ & Isochrysis galbana & $72 \mathrm{~h}$ & $0.01-0.018 \mathrm{mg} / \mathrm{L}^{\mathrm{T}}$ & $50 \%$ inhibition & [68] \\
\hline $\mathrm{Cu}$ & Phaeocystis antarctica & 10 days & $0.0059 \mathrm{mg} / \mathrm{L}$ & $50 \%$ inhibition & {$[60]$} \\
\hline $\mathrm{Cd}$ & Phaeocystis antarctica & 10 days & $1.5 \mathrm{mg} / \mathrm{L}$ & $50 \%$ inhibition & {$[60]$} \\
\hline $\mathrm{Cd}$ & Scenedesmus armatus & $24 \mathrm{~h}$ & $\begin{array}{l}\sim 15-18 \mathrm{mg} / \mathrm{L}^{+} \text {or } \\
0.46-0.54 \mathrm{mg} / \mathrm{L}^{+x}\end{array}$ & $50 \%$ inhibition & [69] \\
\hline $\mathrm{Cd}$ & Thalassiosira weissflogii & - & $4.6 \mathrm{pM}$ & $\begin{array}{l}\sim 30 \%-92 \% \\
\text { stimulation } \mathrm{ZnL}\end{array}$ & {$[44]$} \\
\hline $\mathrm{Ni}$ & Selenastrum capricornutum & - & $0.125 \mathrm{mg} / \mathrm{L}$ & $50 \%$ inhibition & [59] \\
\hline $\mathrm{Ni}$ & Synechococcus sp. & 15 day & $25 \mathrm{mg} / \mathrm{L}$ & $\sim 42 \%$ inhibition & {$[70]$} \\
\hline $\mathrm{Li}$ & Chlorella vannielii & $12 \mathrm{~h}$ & $1000 \mathrm{mg} / \mathrm{L}$ & $48 \%$ inhibition & [30] \\
\hline $\mathrm{Li}$ & Cyanothece sp. & 28 days & $70 \mathrm{mg} / \mathrm{L}$ & Cell death & {$[31]$} \\
\hline $\mathrm{Tl}$ & Chlorella sp. & $72 \mathrm{~h}$ & $80 \mathrm{nmol}$ & $100 \%$ inhibition & {$[71]$} \\
\hline
\end{tabular}


Table 1. Cont.

\begin{tabular}{|c|c|c|c|c|c|}
\hline Metal & Microalgae Strain & $\begin{array}{c}\text { Cultivation } \\
\text { Time }\end{array}$ & Concentration & $\begin{array}{l}\text { Effect on } \\
\text { Growth }\end{array}$ & Ref. \\
\hline $\mathrm{Tl}$ & Synechocystis sp. & $72 \mathrm{~h}$ & $1 \mu \mathrm{M}$ & $50 \%$ inhibition & {$[72]$} \\
\hline Co & Monoraphidium minutum & 11 days & $\begin{array}{c}0.5 \mathrm{ppm} \\
3 \mathrm{ppm}\end{array}$ & $\begin{array}{l}12 \% \text { stimulation } \\
44 \% \text { inhibition }\end{array}$ & [33] \\
\hline $\mathrm{Zn}$ & Phaeocystis antarctica & 10 days & $1.11 \mathrm{mg} / \mathrm{L}$ & $50 \%$ inhibition & {$[60]$} \\
\hline $\mathrm{Zn}$ & Anabaena sp. & $96 \mathrm{~h}$ & $0.38 \mathrm{mg} / \mathrm{L}$ & $50 \%$ inhibition & [73] \\
\hline Al & Dunaliella tertiolecta & $\begin{array}{l}48 \mathrm{~h} \\
48 \mathrm{~h}\end{array}$ & $\begin{array}{c}2.6-14.9 \mathrm{mg} / \mathrm{L} \\
22.42 \mathrm{mg} / \mathrm{L}\end{array}$ & $\begin{array}{l}20 \% \text { stimulation } \\
25 \% \text { inhibition }\end{array}$ & {$[26]$} \\
\hline $\mathrm{Al}$ & Isochrysis galbana & $72 \mathrm{~h}$ & $2.57-3.23 \mathrm{mg} / \mathrm{L}^{\mathrm{T}}$ & $50 \%$ inhibition & {$[68]$} \\
\hline $\mathrm{V}^{\text {Met }}$ & Scenedesmus obliquus & 7 days & $20 \mu \mathrm{g} / \mathrm{L}$ & $\begin{array}{c}534 \% \\
\text { stimulation * }\end{array}$ & {$[37]$} \\
\hline $\mathrm{V}^{\mathrm{Met}}$ & Chlorella pyrenoidosa & 7 days & $1 \mu \mathrm{g} / \mathrm{L}$ & $67 \%$ stimulation & {$[38]$} \\
\hline $\mathrm{V}^{\mathrm{Met}}$ & Chlorella pyrenoidosa & 7 days & $>1 \mathrm{mg} / \mathrm{L}$ & $\begin{array}{l}\text { Inhibitory } \\
\text { threshold }\end{array}$ & {$[38]$} \\
\hline$V^{\text {Ort }}$ & Haematococcus lacustris & 4 days & $2.5-5 \mathrm{mM}$ & Full inhibition & [39] \\
\hline $\mathrm{V}^{\text {Oxi }}$ & Scenedesmus quadricauda & 12 days & $2.23 \mathrm{mg} / \mathrm{L}$ & $50 \%$ inhibition & {$[40]$} \\
\hline $\mathrm{Ce}$ & Desmodesmus quadricauda & 3 days & $6 \mu \mathrm{mol} / \mathrm{L}$ & $16 \%$ stimulation ${ }^{A}$ & {$[41]$} \\
\hline $\mathrm{Ce}$ & Desmodesmus quadricauda & 3 days & $94 \mu \mathrm{mol} / \mathrm{L}$ & $\sim 19 \%$ inhibition $^{A}$ & {$[41]$} \\
\hline $\mathrm{Ce}$ & Desmodesmus quadricauda & 3 days & $5.74 \mu \mathrm{mol} / \mathrm{L}$ & $\begin{array}{l}20 \% \text { inhibition }{ }^{B} \\
60 \% \text { stimulation }\end{array}$ & {$[41]$} \\
\hline $\mathrm{Ce}$ & Desmodesmus quadricauda & 3 days & $1.14 \mu \mathrm{mol} / \mathrm{L}$ & $40 \%$ inhibition $^{D}$ & {$[41]$} \\
\hline $\mathrm{Ce}$ & Anabaena flosaquae & 17 days & $\begin{array}{c}0.1 \mathrm{mg} / \mathrm{L} \\
5-10 \mathrm{mg} / \mathrm{L}\end{array}$ & $\begin{array}{l}\sim 16 \% \text { stimulation } \\
\sim 33 \% \text { inhibition }\end{array}$ & {$[27]$} \\
\hline $\mathrm{La}$ & Desmodesmus quadricauda & 3 days & $5.72 \mu \mathrm{mol} / \mathrm{L}$ & $\begin{array}{l}10 \% \text { inhibition }{ }^{B} \\
80 \% \text { stimulation }^{C}\end{array}$ & {$[41]$} \\
\hline $\mathrm{La}$ & Desmodesmus quadricauda & 3 days & $1.13 \mu \mathrm{mol} / \mathrm{L}$ & No change ${ }^{D}$ & {$[41]$} \\
\hline $\mathrm{La}$ & Scenedesmus quadricauda & $22-23$ days & $72 \mu \mathrm{mol} / \mathrm{L}$ & $50 \%$ inhibition & {$[42]$} \\
\hline $\begin{array}{l}\mathrm{La}, \mathrm{Ce}, \mathrm{Nd}, \\
\text { Sm, Eu, } \\
\text { Gd, Tb, } \\
\mathrm{Dy}, \mathrm{Ho}, \mathrm{Er}, \\
\mathrm{Tm}, \mathrm{Yb}, \mathrm{Lu}\end{array}$ & Skeletonema costatum & $96 \mathrm{~h}$ & $28-29 \mu \mathrm{mol} / \mathrm{L}$ & $50 \%$ inhibition & [43] \\
\hline $\mathrm{Nd}$ & Desmodesmus quadricauda & 3 days & $5.76 \mu \mathrm{mol} / \mathrm{L}$ & $\begin{array}{c}10 \% \text { stimulation } \\
120 \% \\
\text { stimulation }{ }^{C}\end{array}$ & {$[41]$} \\
\hline $\mathrm{Nd}$ & Desmodesmus quadricauda & 3 days & $1.09 \mu \mathrm{mol} / \mathrm{L}$ & $\sim 5 \%$ inhibition ${ }^{D}$ & [41] \\
\hline $\mathrm{TiO}_{2}-\mathrm{NPs}$ & Nitzschia closterium & $96 \mathrm{~h}$ & $88-118 \mathrm{mg} / \mathrm{L}$ & $50 \%$ inhibition & [49] \\
\hline $\mathrm{TiO}_{2}$-NPs & $\begin{array}{c}\text { Pseudokirchneriella } \\
\text { subcapitata }\end{array}$ & $72 \mathrm{~h}$ & $2.53 \mathrm{mg} / \mathrm{L}$ & $50 \%$ inhibition & {$[52]$} \\
\hline $\mathrm{TiO}_{2}-\mathrm{NPs}$ & Chlorella vulgaris & - & $2.5-5 \mathrm{~g} / \mathrm{L}$ & $42 \%$ inhibition & {$[74]$} \\
\hline $\mathrm{ZnO}-\mathrm{NPs}$ & Chlorella vulgaris & $72 \mathrm{~h}$ & $200 \mathrm{mg} / \mathrm{L}$ & $35 \%$ cell viability & {$[50]$} \\
\hline $\mathrm{ZnO}-\mathrm{NPs}$ & Dunaliella tertiolecta & $96 \mathrm{~h}$ & $2.4 \mathrm{mg} / \mathrm{L}$ & $50 \%$ inhibition & {$[56]$} \\
\hline $\mathrm{ZnO}-\mathrm{NPs}$ & $\begin{array}{c}\text { Pseudokirchneriella } \\
\text { subcapitata }\end{array}$ & $72 \mathrm{~h}$ & $0.1 \mathrm{mg} / \mathrm{L}$ & $80 \%$ inhibition & {$[52]$} \\
\hline
\end{tabular}


Table 1. Cont.

\begin{tabular}{|c|c|c|c|c|c|}
\hline Metal & Microalgae Strain & $\begin{array}{c}\text { Cultivation } \\
\text { Time }\end{array}$ & Concentration & $\begin{array}{l}\text { Effect on } \\
\text { Growth }\end{array}$ & Ref. \\
\hline \multirow{3}{*}{$\mathrm{ZnO}-\mathrm{NPs}$} & Phaeodactylum tricornutum & & $100 \mathrm{mg} / \mathrm{L}$ & $80 \%$ inhibition & \multirow{3}{*}{ [51] } \\
\hline & Alexandrium minutum & - & $100 \mathrm{mg} / \mathrm{L}$ & $80 \%$ inhibition & \\
\hline & Tetraselmis suecica & & $100 \mathrm{mg} / \mathrm{L}$ & No effect & \\
\hline ZnO-NPs & Scenedesmus rubescens & $96 \mathrm{~h}$ & $\begin{array}{l}14.27 \mathrm{mg} / \mathrm{L} \text { or } \\
>810 \mathrm{mg} / \mathrm{L}^{\mathrm{CM}}\end{array}$ & $50 \%$ inhibition & [53] \\
\hline $\mathrm{CeO}_{2}$-NPs & $\begin{array}{c}\text { Pseudokirchneriella } \\
\text { subcapitata }\end{array}$ & $72 \mathrm{~h}$ & $4.1-6.2 \mathrm{mg} / \mathrm{L}^{\mathrm{AS}}$ & $50 \%$ inhibition & {$[55]$} \\
\hline \multirow[t]{2}{*}{ NiO-NPs } & Chlorella vulgaris & $120 \mathrm{~h}$ & $44 \mathrm{mg} / \mathrm{L}$ & $50 \%$ inhibition & \multirow[t]{2}{*}{ [75] } \\
\hline & Phaeodactylum tricornutum & & $100 \mathrm{mg} / \mathrm{L}$ & $\sim 40 \%$ inhibition & \\
\hline \multirow[t]{2}{*}{$\mathrm{Y}_{2} \mathrm{O}_{3}-\mathrm{NPs}$} & Alexandrium minutum & - & $100 \mathrm{mg} / \mathrm{L}$ & $\sim 40 \%$ inhibition & \multirow[t]{2}{*}[51]{} \\
\hline & Tetraselmis suecica & & $100 \mathrm{mg} / \mathrm{L}$ & $70 \%$ inhibition & \\
\hline $\begin{array}{l}\mathrm{BaTiO}_{3-} \\
\mathrm{NPs}^{-}\end{array}$ & Chlorella vulgaris & $72 \mathrm{~h}$ & $1 \mathrm{mg} / \mathrm{L}$ & $\sim 57 \%$ inhibition & [76] \\
\hline \multirow{2}{*}{$\mathrm{Al}_{2} \mathrm{O}_{3}-\mathrm{NPs}$} & Chlorella sp. & $72 \mathrm{~h}$ & $45.4 \mathrm{mg} / \mathrm{L}$ & $50 \%$ inhibition & \multirow{2}{*}[54]{} \\
\hline & Scenedesmus sp. & $72 \mathrm{~h}$ & $39.35 \mathrm{mg} / \mathrm{L}$ & $50 \%$ inhibition & \\
\hline $\mathrm{Ag}-\mathrm{NPs}$ & $\begin{array}{c}\text { Pseudokirchneriella } \\
\text { subcapitata }\end{array}$ & $72 \mathrm{~h}$ & $1.63 \mathrm{mg} / \mathrm{L}$ & $50 \%$ inhibition & [77] \\
\hline Pt-NPs & $\begin{array}{c}\text { Pseudokirchneriella } \\
\text { subcapitata }\end{array}$ & $72 \mathrm{~h}$ & $16.9 \mathrm{mg} / \mathrm{L}$ & $50 \%$ inhibition & [77] \\
\hline $\begin{array}{c}\text { nZVI- } \\
\text { Nanofer } 25\end{array}$ & Arthrospira maxima & $216 \mathrm{~h}$ & $5.1 \mathrm{mg} / \mathrm{L}$ & $19 \%$ stimulation & {$[57]$} \\
\hline $\begin{array}{c}\text { nZVI- } \\
\text { Nanofer } 25\end{array}$ & Desmodesmus subspicatus & $216 \mathrm{~h}$ & $5.1 \mathrm{mg} / \mathrm{L}$ & $73 \%$ stimulation & [57] \\
\hline $\begin{array}{c}\text { nZVI- } \\
\text { Nanofer } 25\end{array}$ & Parachlorella kessleri & $216 \mathrm{~h}$ & $5.1 \mathrm{mg} / \mathrm{L}$ & $38 \%$ stimulation & {$[57]$} \\
\hline
\end{tabular}

MMC, Minimum Metal Concentration significantly affecting Chlorophyll a intensity; ${ }^{\mathrm{T}}$, depending on temperature applied; ${ }^{+}$, depending on $\mathrm{Cd}$ salt used; ${ }^{\mathrm{x}}$, including complex abilities of media mineral elements; *, when compared to Scenedesmus growth in Fe deficient medium; ${ }^{\mathrm{ZnL}}$, at low $\mathrm{Zn}$ concentrations; ${ }^{\text {Met }}$, added as metavanadate; ${ }^{\text {Ort }}$, added as orthovanadate; ${ }^{\text {oxi }}$, added as vanadium pentoxide; ${ }^{A}$, in standard medium and compared to a control in standard medium without $\mathrm{Ce} ;{ }^{B}$, in Ca deficient medium and compared to a control in standard medium without tested metal; ${ }^{C}$, in Ca deficient medium and compared to a control in Ca deficient medium without tested metal; ${ }^{D}$, in Mn deficient medium and compared to a control in Mn deficient medium without tested metal; NPs, nanoparticles; ${ }^{\mathrm{CM}}$, depending on culture medium; ${ }^{\mathrm{AS}}$, depending on aged suspension; nZVI, zero-valent iron nanoparticles; Ref., Reference.

\section{Metal Stress as a Method for Stimulation of Bioproduct Synthesis}

Accumulation of metals in microalgae cells consists of two mechanisms: metal adsorption on the cell wall surface containing functional groups (carboxyl, hydroxyl, phosphate, amino, sulfhydryl) and absorption of metals inside cells via metal transport systems [12,19,78]. Metals in microalgae cells can cause formation of reactive oxygen species (ROS) such as hydroxyl radical $(\cdot \mathrm{OH})$, superoxide anion $\left(\mathrm{O}_{2} \cdot{ }^{-}\right)$, singlet oxygen $\left(\mathrm{O}_{2}{ }^{*}\right)$ and hydrogen peroxide $\left(\mathrm{H}_{2} \mathrm{O}_{2}\right)$ that interact with lipids, proteins and nucleic acids, resulting in their degradation. As a protective response to metal induced oxidative stress, 
microalgae cells synthetize chelating agents such as phytochelatin or exopolymers in higher amounts $[12,79,80]$. Chelating agents are organic compounds that form two or more bonds with a metal ion, thereby creating a coordination complex chelate-metal and preventing metal ions from interaction with biological macromolecules [81]. Another defense mechanism againsts oxidative stress is the synthesis of antioxidant compounds (pigments, glutathione, ascorbate) or enzymes (superoxide dismutase, catalase) that are responsible for quenching reactive oxygen species (ROS) and also reducing metal ions into their less reactive forms $[12,79,80]$. Therefore, oxidative stress can be considered as a trigger mechanism to induce production of target compounds by metal-exposed microalgae cells, under conditions where the detrimental effect of metals on microalgal culture is avoided.

\subsection{Pigments}

Chlorophylls, carotenoids and phycobilins are microalgal pigments that harvest light in the process of photosynthesis. Chlorophylls are primary photosynthic pigments that contain tetrapyrrole macrocycle rings and are present in various forms $(a, b, c 1, c 2, c 3, d, f)$, in different microalgae or cyanobacteria species (Table 2). Green microalgae possess chlorophyll content up to 6.7\% [82], and upon chemical modifications, to phaeophytin [83] or $\mathrm{Cu}^{2+}$-chlorophyllin [84], can be used as a biomordant [83] to enchance the dyeing process of textile products or as a textile dye [84] with antimicrobial properties. Additionally, an $\mathrm{Mg}^{2+}$ ion in a chlorophyll centre can be substituted with $\mathrm{Zn}^{2+}, \mathrm{Ni}^{2+}, \mathrm{Cd}^{2+}, \mathrm{Pb}^{2+}, \mathrm{Co}^{2+}$ or $\mathrm{Pt}^{2+}$ [85-90]. Carotenoids-accessory photosynthetic pigments, are fat-soluble tetraterpenoid molecules that are divided into no oxygen-containing carotenes ( $\beta$-carotene) and oxygen-containing xanthophylls (lutein, astaxanthin, zeaxanthin) [91]. Phycobiliproteins are water-soluble proteins that serve as accessory pigments in blue-green or red microalgae, giving a blue (c-phycocyanin, allophycocyanin) [34,92] or pink, red (b-phycoerythrin, c-phycoerythrin) [93,94] colour. Chlorophylls, carotenoids and phycobiliproteins can find applications in food, cosmetic and pharmaceutical products as coloring, antioxidant, food additive or therapeutic agents [95-97].

Table 2. Types of chlorophyll present in eukaryotic microalgae and cyanobacteria.

\begin{tabular}{cccc}
\hline Chlorophyll Type & Microalgae Strain & Taxonomy & Reference \\
\hline $\mathrm{a}, \mathrm{b}$ & Chlorella vulgaris & Green microalgae & {$[98]$} \\
$\mathrm{a}, \mathrm{c} 1, \mathrm{c} 2$ & Phaeodactylum tricornutum & Diatoms & {$[99]$} \\
$\mathrm{a}, \mathrm{c} 1, \mathrm{c} 2$ & Kryptoperidinium foliaceum & Dinoflagellates & {$[100]$} \\
$\mathrm{a}, \mathrm{c} 2, \mathrm{c} 3$ & Karenia mikimotoi & Dinoflagellates & {$[100]$} \\
$\mathrm{a}, \mathrm{d}$ & Acaryochloris marina & Cyanobacteria & {$[101]$} \\
$\mathrm{a}, \mathrm{f}$ & Halomicronema hongdechloris & Cyanobacteria & {$[102]$} \\
\hline
\end{tabular}

The presence of metals can have an enchancing effect on pigment content in microalgae or cyanobacteria cells. Copper $\left(\mathrm{Cu}^{2+}\right)$ at concentration between $0.05-0.2 \mathrm{~g} / \mathrm{L}$ induced $\beta$-carotene production in Chlamydomonas acidophilla [103]. The change in iron $\left(\mathrm{Fe}^{2+}\right)$ medium concentation resulted in a growth improvement and an increase in lutein, zeaxanthin and $\beta$-carotene content in Coccomyxa onubensis cells [104]. Also, $\beta$-carotene content in Dunaliella salina cells was increased seven times in the presence of $450 \mu \mathrm{M} \mathrm{Fe}^{2+}$ and $67.5 \mathrm{mM}$ acetate, however at the expense of four-fold reduction in Dunaliella cell number [105]. Cyanobacterium Nostoc minutum cultivated photoautotrophically in 
medium containg $1 \mathrm{~g} / \mathrm{L}$ arsenic(V) was reported to posses chlorophyll, carotenoid and allophycocyanin content higher by $75 \%, 40 \%$ and $25 \%$, respectively, when compared to control culture [34]. Similarly, small concentrations of $\mathrm{Ni}(0.1-10 \mu \mathrm{M})$ increased chlorophyll content and c-phycocyanin production even by $47 \%$ and up to 4.35 times, respectively, in Anabaena doliolum culture [92]. The content of c-phycocyanin, phycoerythrin and allophycocyanin in cyanobacterium Phormidium tenue culture increased considerably in the presence of As, but the uplift profiles were strongly dependent on As dosage (0.1-100 ppm) and exposure time [106]. In other studies, cultivation of Synechocystis sp. in the presence of $\mathrm{Pb}$ and $\mathrm{Cd}$, and Spirulina platensis in the presence of $\mathrm{Pb}$, showed a decrease in biomass and pigment (chlorophyll, carotenoid, phycocyanin) concentration, in the culture volume. Nevertheless, pigment content in cyanobacteria biomass increased at some metal concentrations and cyanobacteria growth was stimulated at low $\mathrm{Pb}$ concentrations [107,108]. Lead $(\mathrm{Pb})$ and cadmium $(\mathrm{Cd})$ at concentrations up to $10 \mathrm{mg} / \mathrm{L}$ increased chlorophyll concentration in cultures of metal resistant Scenedesmus quadricauda and Pseudochlorococcum typicum [109]. Tellurium $\left(\mathrm{TeO}_{3}{ }^{2-}\right)$, added into Spirulina platensis growth media, was accumulated and incorporated into peptides in Spirulina cells. As a result, production of Te-phycocyanin and Te-allophycocyanin possessing enhanced antioxidant activity, was reported in Spirulina platensis cells [110].

\subsection{Lipids}

Microalgal cells are a source of lipids including triacyloglycerols (TAGs) and fatty acids [111], but also phytosterols [112] and sphingolipids [113], with potential applications as biofuels, nutraceuticals and food additives. It is reported that nutrient deficiency such as nitrogen deprivation results in oxidative stress and lipid accumulation in microalgal cells [114]. Cultivation of Chlorella minutissima in the presence of $\mathrm{Cd}(0.2-0.4 \mathrm{mM})$ or $\mathrm{Cu}(0.2-1 \mathrm{mM})$ leads to the increase in both biomass density and cell lipid content, providing lipid productivity improved 2.17 -fold with $0.4 \mathrm{mM} \mathrm{Cd}$ or by $34 \%$ with $0.4 \mathrm{mM}$ $\mathrm{Cu}$ [115]. Euglena gracilis cultivated photoautotrophically or mixotrophically in the presence of low chromium $\left(\mathrm{Cr}^{6+}\right)$ concentration exhibited higher total lipid content, although lipid stimulation $(10 \%-100 \%)$ was dependent on Euglena strain used and medium composition tested [116]. Addition of $0.1 \mathrm{~g} / \mathrm{L} \mathrm{TiO}_{2}$ nanoparticles with UV-A irradiation applied, slightly increased production of fatty acids in Chlorella vulgaris cells, without growth reduction [74]. Recently, zero-valent iron nanoparticles $(5.1 \mathrm{mg} / \mathrm{L})$ were reported to increase lipid productivity in Arthrospira maxima, Desmodesmus subspicatus and Parachlorella kessleri cultures, respectively by $40 \%, 2.75$-fold and by $66 \%$ [57]. Metal stress also causes the alteration of fatty acid profile in microalgae cells. The effect of As(III) on Nannochloropsis sp. cells resulted in a slight increase in cell lipid content and a change in lipid profile, as the decrease in polyunsaturated fatty acids and the increase in short-chain saturated $(\mathrm{C} 16: 0, \mathrm{C} 18: 0)$ and monounsaturated (C16:1, C18:1) fatty acids, was depicted [117]. Nickel at $0.5 \mathrm{mg} / \mathrm{L}$ caused a shift of fatty acid profile towards saturated fatty acids (C14:0, C16:0, C20:0) in Dunaliella salina and Nannochloropsis salina cells, also with the upshift of saturated C18:0 and unsaturated C18:2 for Nannochloropsis and C22:0 behenic acid for Dunaliella [118]. Composition of fatty acids (chain length, number of double bonds) defines the biodiesels produced from corresponding triglycerides in terms of their quality and properties (including cetane number, density, viscosity, lubricity, calorific value, $\mathrm{NO}_{x}$ emissions) [119-121]. Therefore, metal stress can be applied to alter composition of fatty acids in microalgal cells and produce 
biodiesel of desirable quality and properties [117]. As a contrary, cultivation of Nannochloropsis limnetica and Trachydiscus minutus in the presence of zero-valent iron nanoparticles (nZVI) caused the decrease in saturated fatty acids (C14:0, C16:0, C18:0) and the increase in eicosapentaenoic acid (C20:5 03 ) content in Nannochloropsis and Trachydiscus biomass [57]. Eicosapentaenoic acid (EPA) can be used as a nutraceutical or pharmacological agent for the treatment of heart and inflammatory diseases [122].

\subsection{Exopolymers}

Extracellular polymeric substances (EPS), consisting of exopolysaccharides and exoproteins, are excreted by microalgae and cyanobacteria upon exposure to stress factors such as nutrient $(\mathrm{N}, \mathrm{P})$ imbalance, but the release mechanism can also depend on cultivation conditions (light intensity, temperature, salinity, microelement availability) and the stage of microalgal growth [123-128]. Exopolysaccharides can be of linear or branched structure and contain C6 (glucose, galactose, fructose, rhamnose, fucose) and C5 (xylose, arabinose) sugars, as well as uronic (glucuronic, galacturonic) acids, aromatic, pyruvate, acetate, sulphate and halide groups. Additionally, extracellular polysaccharides can be also coupled with peptides, lipids and nucleic acids $[129,130]$.

Metals were reported to stimulate the release of exopolymers by microalgal cells. A considerable increase in the release of exopolysaccharides and extracellullar proteins was observed in the culture of cyanobacterium Lyngbya putealis, as a response to the presence of $\mathrm{Cu}$ and $\mathrm{Co}$ [131]. Increased release of extracellular polymers from Thalassiosira weissflogii [132], and Thalassiosira pseudonana [133] in the presence of $\mathrm{Ag}$ [132] and $\mathrm{Cd}$ [133] ions released from engineered nanoparticles (ENPs), was also reported. Extracellular polymeric substances possess antiviral, antitumor, anticoagulant, antiinflammatory and immunostimulant activity, but they can also serve as biosurfactants, biolubricants, bioemulsifiers [130] and a source of sugars for biofuels [134].

\subsection{Phytochelatin}

Phytochelatins are (oligo)peptides synthetized in plants, yeast, algae and cyanobacteria for detoxification of heavy metals. The structure of phytochelatin is ( $\gamma$-Glu-Cys)n-Gly with $\gamma$-Glu-Cys $n$ being between 2 to 11 . Phytochelatin is synthetized by phytochelatin synthase (glutathione- $\gamma$ glutamylcysteinyltransferase), by firstly adding $\gamma$-Glu-Cys from glutathione ( $\gamma$-Glu-Cys-Gly) to another glutathione molecule forming ( $\gamma$-Glu-Cys) $)_{2}-\mathrm{Gly}$ (PC2) and further incorporates new $\gamma$-Glu-Cys units into PC2 [135]. Synthesis of short chain phytochelatins (2 to 6 of $\gamma$-Glu-Cys units) was reported in cells of microalgae (Table 3) such as Scenedesmus vacuolatus [136], Phaeodactylum tricornutum [137-139], Scenedesmus armatus [140], Stichococcus bacillaris [141], Micrasterias denticulata [142] and cyanobacterium Anabaena doliolum [143] exposed to increasing concentration of Cd, $\mathrm{Pb}, \mathrm{Cu}$ and/or As. Phytochelatin content in Scenedesmus armatus and Stichococcus bacillaris cells exposed to constant (Const.) concentration of $\mathrm{Cd}$ and As respectively can be also further elevated, with the upshift of $\mathrm{CO}_{2}$ supplementation for Scenedesmus [140] and decrease of pH for Stichococcus [141]. Also synthesis of iso-phytochelatins such as $\mathrm{Cys}(\mathrm{GluCys})_{n}$ Gly and (GluCys) ${ }_{n} \mathrm{Ala}$ was reported in Chlamydomonas reinhardtii upon $\mathrm{Cd}$ exposure [144]. Phytochelatins, obtained from microalgae cultures, can become a 
component for biosensors, designed for detection of heavy metals in samples of environmental, biological or pharmaceutical origin $[145,146]$.

Table 3. Synthesis of phytochelatin in microalgae exposed to heavy metals.

\begin{tabular}{|c|c|c|c|c|c|c|}
\hline Strain & Metal & $\begin{array}{l}\text { Metal } \\
\text { Uplift }\end{array}$ & Phytochelatin Uplift & $\mathbf{P C N}^{\mathrm{A}}$ & Growth Rate ${ }^{\mathrm{C}}$ & Reference \\
\hline $\begin{array}{c}\text { Scenedesmus } \\
\text { vacuolatus }\end{array}$ & $\mathrm{Cd}$ & $\begin{array}{c}0.3 \rightarrow \\
79 \mathrm{nM}\end{array}$ & $\begin{array}{l}\sim 3 \rightarrow 25 \mathrm{amol} / \text { cell } \\
\sim 1 \rightarrow 44 \mathrm{amol} / \mathrm{cell} \\
\sim 0 \rightarrow 17 \mathrm{amol} / \mathrm{cell}\end{array}$ & $\begin{array}{l}\mathrm{PC} 2 \\
\mathrm{PC} 3 \\
\mathrm{PC} 4 \\
\end{array}$ & $\begin{array}{c}\text { Reduced by } \\
37 \%\end{array}$ & [136] \\
\hline $\begin{array}{c}\text { Phaeodactylum } \\
\text { tricornutum }\end{array}$ & $\mathrm{Cd}$ & $\begin{array}{c}0 \rightarrow \\
0.45 \mu \mathrm{M}\end{array}$ & $\begin{array}{c}\sim 0.16 \rightarrow 3.6 \mathrm{amol} / \mathrm{cell} \\
\sim 0.5 \rightarrow 1.3 \mathrm{amol} / \mathrm{cell} \\
\sim 0.05 \rightarrow 1.5 \mathrm{amol} / \mathrm{cell}\end{array}$ & $\begin{array}{l}\mathrm{PC} 2 \\
\mathrm{PC} 3 \\
\mathrm{PC} 4\end{array}$ & No change & [137] \\
\hline $\begin{array}{c}\text { Phaeodactylum } \\
\text { tricornutum }\end{array}$ & $\mathrm{Cu}$ & $\begin{array}{c}0.068 \mathrm{pM} \rightarrow \\
0.4 \mu \mathrm{M}\end{array}$ & $\begin{array}{c}\sim 0.16 \rightarrow 1.7 \mathrm{amol} / \mathrm{cell} \\
\sim 0.5 \rightarrow 1.5 \mathrm{amol} / \mathrm{cell} \\
\sim 0.05 \rightarrow 0.8 \mathrm{amol} / \mathrm{cell}\end{array}$ & $\begin{array}{l}\mathrm{PC} 2 \\
\mathrm{PC} 3 \\
\mathrm{PC} 4 \\
\end{array}$ & No change & [137] \\
\hline $\begin{array}{c}\text { Phaeodactylum } \\
\text { tricornutum }\end{array}$ & $\mathrm{Cd}$ & $0 \rightarrow 10 \mu \mathrm{M}$ & $\begin{array}{l}\sim 0 \rightarrow 12.5 \mathrm{amol} / \mathrm{cell} \\
\sim 0 \rightarrow 25 \mathrm{amol} / \mathrm{cell} \\
\sim 0 \rightarrow 5 \mathrm{amol} / \mathrm{cell}\end{array}$ & $\begin{array}{l}\mathrm{PC} 2 \\
\mathrm{PC} 4 \\
\mathrm{PC} 5\end{array}$ & $\begin{array}{l}\text { Toxic effect } \\
\text { avoided }\end{array}$ & [138] \\
\hline $\begin{array}{c}\text { Phaeodactylum } \\
\text { tricornutum }\end{array}$ & $\mathrm{Pb}$ & $0 \rightarrow 10 \mu \mathrm{M}$ & $\begin{array}{l}\sim 0 \rightarrow 50 \mathrm{amol} / \mathrm{cell} \\
\sim 0 \rightarrow 13 \mathrm{amol} / \mathrm{cell} \\
\sim 0 \rightarrow 3 \mathrm{amol} / \mathrm{cell}\end{array}$ & $\begin{array}{l}\mathrm{PC} 2 \\
\mathrm{PC} 3 \\
\mathrm{PC} 5\end{array}$ & $\begin{array}{l}\text { Toxic effect } \\
\text { avoided }\end{array}$ & {$[138]$} \\
\hline $\begin{array}{c}\text { Phaeodactylum } \\
\text { tricornutum }\end{array}$ & $\mathrm{Cu}$ & $0 \rightarrow 10 \mu \mathrm{M}$ & $\begin{array}{l}\sim 2 \rightarrow 18 \mathrm{amol} / \text { cell } \\
\sim 0 \rightarrow 38 \mathrm{amol} / \mathrm{cell} \\
\sim 0 \rightarrow 5 \mathrm{amol} / \mathrm{cell}\end{array}$ & $\begin{array}{l}\mathrm{PC} 2 \\
\mathrm{PC} 3 \\
\mathrm{PC} 6 \\
\end{array}$ & - & [139] \\
\hline $\begin{array}{l}\text { Scenedesmus } \\
\text { armatus }\end{array}$ & $\mathrm{Cd}$ & $\begin{array}{l}\text { Const. } \\
93 \mu \mathrm{M} *\end{array}$ & $\begin{array}{c}\sim 40 \rightarrow 200 \mathrm{nmol}-\mathrm{SH} / \mathrm{g} \\
\sim 80 \rightarrow 1300 \mathrm{nmol}-\mathrm{SH} / \mathrm{g} \\
\sim 20 \rightarrow 280 \mathrm{nmol}-\mathrm{SH} / \mathrm{g}\end{array}$ & $\begin{array}{l}\mathrm{PC} 2 \\
\mathrm{PC} 3 \\
\mathrm{PC} 4\end{array}$ & $\begin{array}{c}\text { Reduced by } \\
26 \%\end{array}$ & {$[140]$} \\
\hline $\begin{array}{c}\text { Stichococcus } \\
\text { bacillaris }\end{array}$ & $\mathrm{As}(\mathrm{V})$ & $\begin{array}{c}\text { Const. } \\
100 \mu \mathrm{M} * * \\
\text { Const. } \\
100 \mu \mathrm{M} * *\end{array}$ & $\begin{array}{l}0.07 \rightarrow 0.15 \mu \mathrm{mol}-\mathrm{SH} / \mathrm{g} \\
0.14 \rightarrow 0.38 \mu \mathrm{mol}-\mathrm{SH} / \mathrm{g}\end{array}$ & $\mathrm{PC} 2$ & $\begin{array}{c}\text { Reduced by } \\
20 \% \\
\text { Reduced by } \\
30 \% \\
\end{array}$ & {$[141]$} \\
\hline
\end{tabular}

A Phytochelatin with $\mathrm{N}$ number of $\gamma$ Glu-Cys units; ${ }^{\mathrm{C}}$ when compared to control; * increase of $\mathrm{CO}_{2}$ supplementation from $0.1 \%$ to $2 \%$; ** $\mathrm{pH}$ shift from 8.2 to 6.8 .

\subsection{Phytohormones}

Zeatin, indoleacetic acid and abscisic acid are phytohormones that can be used as growth regulators for plants [147,148], and yeast [149], but also as anti-aging agents [150] and potential drugs for neural [151] or cancer [152] diseases. Phytohormones can be found in microalgae [153] and their content can be amplified in the presence of heavy metals. The content of indoleacetic acid, zeatin and abscisic acid increased in Chlorella vulgaris cells grown in the medium containing $10^{-4} \mathrm{M} \mathrm{Cd}, \mathrm{Pb}$ or $\mathrm{Cu}$, however at the expense of decreased cell number in the culture. Interestingly, addition of $10^{-8} \mathrm{M}$ brassinolide into metal-containing Chlorella culture enabled to achieve cell number comparable to control culture, together with further stimulation of zeatin, indoleacetic acid and abscisic acid production [154]. 


\subsection{Organoarsenical Compounds}

Accumulation of As in microalgae cells has been recently extensively summarized [155]. In essence, the uptake of $\mathrm{As}(\mathrm{V})$ from surroundings into microalgae cells is accomplished by means of phosphate transport system, while As(III) is transported by aquaglyceroporins and hexose permeases [155]. Subsequently, $\mathrm{As}(\mathrm{V})$ is reduced to As(III) via As reductase action, with simultaneous oxidation of glutathione (GSH). As(III) undergoes methylation via As methyltransferase action into monomethylarsonate (MMA) and dimethylarsinate (DMA). Arsenic(III) can also undergo bio-oxidation to As(V) or be extruded from cells [156-158]. Arsenic(V) can be incorporated into cellular components such as sugars and lipids. In microalgae, dimethylarsinate (or its reduced form: dimethylarsinous acid) can combine with the adenosyl group from $S$-adenosyl methionine, leading to formation of a dimethylarsinyladenosine, which further undergoes glycosidation to dimethylarsenoribosides [159,160]. In cyanobacteria, dimethylarsinate undergoes reduction, ribose-coupling and glycosidation [161]. Some varieties of arsenosugars containing glycerol, sulphate, sulphonate and phosphate groups were detected for microalgae [160,162]. Arsenolipids in microalgae were determined as dimethylarsenoriboside phospholipids (Figure 1), although phospholipids containing single As(V) or DMA groups were also reported [163]. Content and compositions of arsenoorganics formed in microalgae Chlorella and Monoraphidium [65], Dunaliella and Phaeodactylum [163], Chlamydomonas [160] or cyanobacteria Synechocystis [157,161] and Nostoc [161] cells depends on microalgae strain used, as well as on arsenic(V) concentration applied, exposure time and phosphate availability. Arsenolipids and arsenosugars are currently evaluated as possible therapeutic agents [164]. However, application of As-containing compounds is limited due to high toxicity and so far, only derivatives of arsenolipids have been reported to possess any medical applications [159].

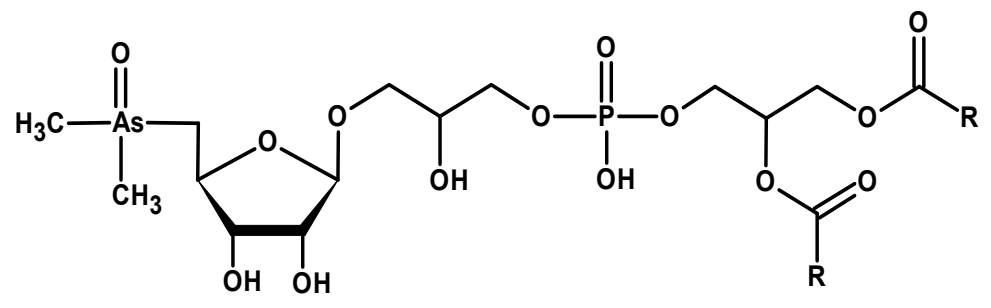

Figure 1. Chemical structure of dimethylarsenoriboside phospholipids ( $\mathrm{R}-\mathrm{a}$ carbon chain of fatty acid).

\subsection{Nanoparticles and Nano-Needles}

Nanoparticles are particles with sizes ranging between 1-100 nm [165]. Nanoparticles possess antiviral, antibacterial, antifungal, anticancer and antiparasite activity. They also find application in the field of catalysis or photonics or can serve as drug carriers and components of chemical sensors [166]. Methods applied for manufacturing nanoparticles range from mechanical, laser and UV irradiation treatment to microemulsion system, hydrothermal process, sol-gel process, chemical vapor condensation, sonochemical treatment and microbial biosynthesis [165,167]. Synthesis of nanoparticles by microorganisms (bacteria, yeast, fungi and microalgae) can constitute a green and environmentally friendly method for nanoparticles production [168,169]. Formation of nanoparticles: Au, Ag or Pd 
(Table 4) from metal ions solutions takes place inside microalgae cells (intracellularly) or in the media (extracellularly) via interactions with molecules of microalgal cell metabolism (NADH, pigments, peptides, proteins and polysaccharides) [170-176]. The size of synthetized nanoparticles depends on microalgal strain and metal type used, but place of synthesis, initial metal loading, light and temperature are also crucial factors influencing formation of nanoparticles. Additionally, synthesis of $\mathrm{Cd}$ nanoparticles in a form of CdS [177] or Ni nanoparticles as a product of reduction of other nanoparticles (NiO) [75], was also reported. Besides nanoparticles, biosynthesis of nanoneedles by microalgae also occurs; such nanoneedles, composed of zinc and phosphorous, were detected in Scenedesmus obliquus cells as a result of exposure to high $\mathrm{Zn}$ concentration [178].

Table 4. Synthesis of nanoparticles (NP) in microalgae and cyanobacteria cultures.

\begin{tabular}{|c|c|c|c|c|c|}
\hline Element NP & Source & Strain & $\begin{array}{c}\text { Place of } \\
\text { Synthesis }\end{array}$ & $\begin{array}{c}\text { Average Particle } \\
\text { Size (nm) }\end{array}$ & Reference \\
\hline Gold (Au) & $\mathrm{HAuCl}_{4} \cdot 3 \mathrm{H}_{2} \mathrm{O}$ & Chlorella vulgaris & Intracellularly & $40-60$ & [170] \\
\hline Gold (Au) & $\mathrm{KAuCl}_{4}$ & Eolimna minima & Intracellularly & $5-100$ & [171] \\
\hline Silver (Ag) & $\mathrm{AgNO}_{3}$ & $\begin{array}{c}\text { Parachlorella } \\
\text { kessleri }\end{array}$ & Extracellularly & 9,14 or 18 & {$[172]$} \\
\hline Silver (Ag) & $\mathrm{AgNO}_{3}$ & $\begin{array}{c}\text { Botryococcus } \\
\text { braunii }\end{array}$ & Extracellularly & 15.67 & [173] \\
\hline Silver (Ag) & $\mathrm{AgNO}_{3}$ & Scenedesmus sp. & Intracellularly & $15-20$ & [174] \\
\hline Palladium (Pd) & $\mathrm{Na}_{2}\left(\mathrm{PdCl}_{4}\right)$ & Chlorella vulgaris & $\begin{array}{l}\text { Microalga } \\
\text { culture }\end{array}$ & 7 & {$[175]$} \\
\hline Palladium (Pd) & $\mathrm{PdCl}_{2}$ & Chlorella vulgaris & Intracellularly & $5-12$ & {$[170]$} \\
\hline Palladium (Pd) & $\mathrm{PdCl}_{2}$ & $\begin{array}{c}\text { Plectonema } \\
\text { boryanum }\end{array}$ & Extracellularly & $\leq 30$ & [176] \\
\hline $\begin{array}{c}\text { Cadmium } \\
\text { sulphide }(\mathrm{CdS})\end{array}$ & $\mathrm{Cd}\left(\mathrm{NO}_{3}\right)_{2} \cdot 4 \mathrm{H}_{2} \mathrm{O}$ & Scenedesmus & Intracellularly & $\begin{array}{c}120-175 \\
\text { (described as } \\
\text { nanoparticles) }\end{array}$ & [177] \\
\hline Nickel (Ni) & $\mathrm{NiO}-\mathrm{NPs}$ & Chlorella vulgaris & $\begin{array}{l}\text { Microalga } \\
\text { culture }\end{array}$ & - & [75] \\
\hline
\end{tabular}

\section{Influence of Growth Conditions on Microalgal Resistance Towards Metals}

Metals at low concentration can be stimulatory for growth and production of target compounds, but metal overdose has detrimental and lethal effects on microalgae cultures. Hence, microalgal cultivation in metal polluted wastewaters should be designed in such a way to limit cell-metal interactions to the level at which metal concentration exerts only beneficial effects on microalgae growth and biosynthesis of crucial products. Microalgal cell response to metal presence depends on many factors such as conditions of cultivation, nutrient availability, presence of organic compounds and tolerance ability of particular strains.

\subsection{Growth Media Composition and Cultivation Conditions}

Composition of growth media is a crucial factor regarding microalgae response towards heavy metals, such as arsenic, cadmium or nickel. 
Arsenate $\left(\mathrm{AsO}_{4}{ }^{3-}\right)$ and phosphate $\left(\mathrm{PO}_{4}{ }^{3-}\right)$ are mutual competitors for the uptake by microalgal cells [155]. A 10-fold increase in phosphate concentation resulted in a 18 times higher resistance of Monoraphidium arcuatum against $\mathrm{As}(\mathrm{V})$. On the other hand, a 10-fold decrease in medium nitrate $\mathrm{NO}_{3}{ }^{-}$content at ordinary $\left(\mathrm{PO}_{4}{ }^{3-}\right.$ ) concentation, decreased by $28 \%$ Monoraphidium resistance towards arsenic [65]. In another study, a 131-fold phosphate uplift improved 516 times resistance of Chlorella salina against As(V) [35]. Indeed, increasing concentration of As(V) stimulated growth of arsene tolerant Chlorella sp. at low phosphate $(\mathrm{P})$ concentration, although cell yields obtained were lower than in experiments with high $\mathrm{P}$ concentration [36]. Concentration of $\mathrm{PO}_{4}{ }^{3-}$ in medium in relation to dissolved lead content can be also important, as $\mathrm{Pb}^{2+}$ can precipitate in a form of $\mathrm{Pb}_{3}\left(\mathrm{PO}_{4}\right)_{2}$, thereby removing available phosphate from solution and inhibiting growth of Chlamydomonas reinhardtii [179].

Sulphur is a component of cysteine that participates in the defense mechanisms against heavy metals. The resistance of Chlamydomonas moewusii exposed to $4 \mathrm{mg} / \mathrm{L}$ cadmium can be improved five times and cysteine cell content can be raised 10 times, when sulphate $\left(\mathrm{SO}_{4}{ }^{2-}\right)$ concentration in medium is increased 100 times [180]. In another study, a 10-fold increase in $\mathrm{SO}_{4}{ }^{2-}$ supply resulted in a Chlamydomonas reinhardtii resistance improved by up to $77 \%$ towards $\mathrm{Cd}$. Improved Chlamydomonas resistance was accompanied with an increased activity of cysteine desulfhydrase, an enzyme responsible for the cleavage of cysteine into pyruvate, $\mathrm{NH}_{3}$ and sulfide, the latter one reported to react with $\mathrm{Cd}$ to form CdS [181].

A 20-fold increase in ammonium $\left(\mathrm{NH}_{4}{ }^{+}\right)$concentration increased five times the accumulation of $\mathrm{PO}_{4}{ }^{3-}$ in Chlorella vulgaris cells and caused a 50\% alleviation in inhibition of Chlorella growth exerted by chromium $(\mathrm{Cr})$ [182]. Increase in magnesium $\left(\mathrm{Mg}^{2+}\right)$ and hydrogen $\left(\mathrm{H}^{+}\right)$concentration reduced nickel toxicity towards Pseudokirchneriella subcapitata, as $\mathrm{Mg}^{2+}$ and $\mathrm{H}^{+}$compete with $\mathrm{Ni}^{2+}$ for the uptake by the cell transport system [183]. In other studies, an increase in $\mathrm{H}^{+}$concentration was reported to improve, even up to 23 times [184], Chlorella sp. resistance against $\mathrm{Cu}$.

$\mathrm{Zn}$ alleviated detrimental effects of $\mathrm{Cr}$ on the photosynthetic mechanism in Micrasterias denticulata cells and $\mathrm{Fe}$ ameliorated inhibitory effect of $\mathrm{Cd}$ and $\mathrm{Cr}$ on Micrasterias cell development. $\mathrm{Ca}$ and $\mathrm{Gd}$ were reported to prevent alterations in cell morphology caused by $\mathrm{Pb}$ and $\mathrm{Cd}$, thereby nullifying negative effects of $\mathrm{Pb}$ and $\mathrm{Cd}$ on Micrasterias cells [185].

Finally, toxicity of thallium towards Chlorella sp. was completely alleviated, when concentration of $\mathrm{K}^{+}$in media was increased 20 times, presumably due to competive uptake in Chlorella cell transport systems [71].

Cultivation parameters such as light intensity and $\mathrm{CO}_{2}$ concentration are also important factors affecting microalgae response towards metals. Alterations in ligh irradiance had influence on inhibition or stimulation of Chlamydomonas reinhardtii growth under different $\mathrm{Cu}$ concentrations, and also affected accumulation of $\mathrm{Cu}$ in Chlamydomonas cells [186]. Increase of $\mathrm{CO}_{2}$ supply enabled the alleviation of the inhibitory effect of Cd towards Scenedesmus armatus, although growth inhibition was not entirely overcome [140]. 


\subsection{Supportive Compounds}

Another modulating approach could be supplementation of microalgae cultures with organic compounds such as phytohormones or chelating agents.

\subsubsection{Phytohormones: Modulating Effect}

Phytohormones - spermidine (polyamine), gibberellin and many representatives of auxin and cytokinin groups - were reported to prevent inhibition of Chlorella vulgaris culture exposed to cadmium $(\mathrm{Cd})$, copper $(\mathrm{Cu})$ or lead $(\mathrm{Pb})$ at a concentration of $0.1 \mathrm{mM}$. What is more, addition of compounds from the cytokinin group such as benzyladenine, zeatin, kinetin, 2-isopentenyladenine, diphenylurea, forchlorphenuron and thidiazuron not only enabled restoration of the Chlorella culture, but also increased cell number by up to $77 \%$, when compared to control. Supplementation of spermidine, gibberellin, auxins or cytokinins generally increased not only the content of chlorophyll, carotenoid, protein, ascorbate and glutathione in Chlorella cells, but also activity of superoxide dismutase and catalase [187]. In earlier studies, it was stated that the inhibitory effect of $0.1 \mathrm{mM} \mathrm{Cd}, \mathrm{Cu}$ and $\mathrm{Pb}$ on Chlorella vulgaris culture can be also nullified in the presence of brassinolide [154].

\subsubsection{Chelating Agents: Modulating Effect}

Chelating agents are synthetized by microalgae for intracellular (phytochelatin, glutathione) or extracellular (exopolymers) detoxification of metals, but can also be added artificially into growth media to bind metals and modulate cell-metal interactions. Such agents can be low-molecular organic acids (ethylenediamine tetraacetic acid, nitrilotriacetic acid, citrate) or humic substances: humic acid or fulvic acid (Table 5).

Addition of $34 \mu \mathrm{M}$ ethylenediamine tetraacetic acid (EDTA) into Scenedesmus subspicatus culture enabled a $\sim 55 \%$ reduction in growth inhibition exerted by $\sim 40 \mu \mathrm{M} \mathrm{Cu}$ [188]. Also EDTA, as well as nitrilotriacetic acid (NTA) and citrate (Cit), were reported to prevent accumulation of lanthanum (La), gadolinum (Gd) and yttrium (Y) in Chlorella vulgaris cells, with reduction in accumulation around 10- to 30-fold higher for EDTA, when compared to NTA and Cit [189]. On the other hand, citrate was reported to enhance $\mathrm{Cd}(0.25 \mu \mathrm{M} / \mathrm{L})$ accumulation and growth inhibition of Selenastrum capricornutum, due to the occasional uptake of Cd-citrate by cells [190]. With the absence of EDTA in growth medium, cadmium (Cd) exerted much stronger inhibitory effects on Scenedesmus armatus, when compared to the growth in EDTA-containing medium [69]. Growth of Scenedesmus quadricauda or Microcystis aeruginosa in the presence of lanthanum $(0.72-72 \mu \mathrm{M})$ and EDTA $(0.269-26.9 \mu \mathrm{M})$ was inhibited or enhanced, depending on La and EDTA concentrations. EDTA $(2.69-13.4 \mu \mathrm{M})$ vastly alleviated the inhibitory effect of La on Microcystis growth, although EDTA alone and at higher concentration had strong inhibitory effects towards Microcystis [42]. EDTA [37,191,192] or citrate [37,193] increased $\mathrm{Fe}$ availability to microalgae, although high concentration of chelating agent can have opposite effects [42,191]. Additionally, EDTA that fails to maintain availabilily of $\mathrm{Fe}$ at high $\mathrm{pH}$ during Spirulina cultivation, can be replaced by alternative chelating agents such as Fe complexes of $N, N^{\prime}$-bis(2-hydroxybenzyl)ethylenediamine- $N, N^{\prime}$-diacetic acid 
(HBED), ethylenediamine- $N, N^{\prime}$-bis((2-hydroxyphenyl)acetic acid) (EDDHA) or ethylenediamine- $N, N^{\prime}-$ bis((2-hydroxy-4-methylphenyl)acetic acid) (EDDHMA) [194].

Humic acid was reported to protect Dunaliella salina and Nannochloropsis salina cells against $\mathrm{Ni}^{2+}$ stress, by means of forming humic acid- $\mathrm{Ni}^{2+}$ complexes and/or by adsorbing on cell surface and thus, creating an additional barrier for $\mathrm{Ni}^{2+}$ uptake [118]. Similarly, humic acids reduced toxicity of $\mathrm{Cd}^{2+}$ and $\mathrm{Zn}^{2+}$ towards Pseudokirchneriella subcapitata [195], $\mathrm{Hg}^{2+}$ towards Isochrysis galbana [196] and $\mathrm{ZnO}$ nanoparticles towards Anabaena sp [197]. Humic acid itself at 7 and 2.5-10 mg/L stimulated growth of Isochrysis galbana [198] and Stichococcus bacillaris [141], presumably due to improved nutrient uptake via humic acid-cell membranes interaction [198]. However, an opposite effect, enhanced toxicity of $\mathrm{Pb}$ towards Isochrysis in the presence humic acid, was also observed [198], because the formation of a ternary complex between $\mathrm{Pb}$, humic acid and microalga cell surface, enhances internalization of $\mathrm{Pb}$ [199]. Humic acid was also reported to be inhibitory $(0.3 \mathrm{mg} / \mathrm{L})$ and lethal $(1 \mathrm{mg} / \mathrm{L})$ for Anabaena circinalis, probably due to its chelating activity towards $\mathrm{Fe}^{3+}$, leading to the decrease in availability of Fe necessary for Anabaena growth [200]. It is also noteworthy, that humic acid can undergo degradation under high light irradiance, leading to the decreased capacity for metal complexation [201]. Fulvic acid contributed to protection of Scenedesmus subspicatus against $\mathrm{Cu}^{2+}$ [188], but no protective effect against $\mathrm{Cd}^{2+}$ and $\mathrm{Zn}^{2+}$ was found for Pseudokirchneriella subcapitata [195]. Fulvic acid was also reported to serve as a source of phosphorus to nullify toxic effects of aluminum (Al) on P-metabolism in Chlorella pyrenoidosa [202].

Table 5. Effect of humic and fulvic acids on microalgae response towards metals.

\begin{tabular}{|c|c|c|c|c|c|}
\hline Chelating Agent & Metal & $\begin{array}{c}\text { Uplift of } \\
\text { Chelating Agent } \\
\text { Concentration } \\
\end{array}$ & Strain & $\begin{array}{c}\text { Reduction of } \\
\text { Growth } \\
\text { Inhibition } \\
\end{array}$ & Reference \\
\hline Humic acid (Soil) & $\begin{array}{c}\mathrm{Ni}^{2+} \\
(0.5 \mathrm{mg} / \mathrm{L})\end{array}$ & $0 \rightarrow 0.2 \mathrm{mg} / \mathrm{L}$ & $\begin{array}{c}\text { Dunaliella salina } \\
\text { Nannochloropsis } \\
\text { salina }\end{array}$ & $\begin{array}{l}40 \%{ }^{\mathrm{A}} \rightarrow 25 \%^{\mathrm{C}} \\
30 \%^{\mathrm{A}} \rightarrow 15 \%{ }^{\mathrm{C}}\end{array}$ & [118] \\
\hline Humic acid (Soil) & $\begin{array}{c}\mathrm{Cd}^{2+} \\
(0.2 \mathrm{mg} / \mathrm{L}) \\
\end{array}$ & $0 \rightarrow 5 \mathrm{mg} / \mathrm{L}$ & $\begin{array}{c}\text { Pseudokirchneriella } \\
\text { subcapitata }\end{array}$ & $52 \%{ }^{\mathrm{A}} \rightarrow 28 \%{ }^{\mathrm{C}}$ & [195] \\
\hline Humic acid (Soil) & $\begin{array}{c}\mathrm{Zn}^{2+} \\
(0.39 \mathrm{mg} / \mathrm{L}) \\
\end{array}$ & $0 \rightarrow 5 \mathrm{mg} / \mathrm{L}$ & $\begin{array}{c}\text { Pseudokirchneriella } \\
\text { subcapitata }\end{array}$ & $55 \%{ }^{\mathrm{A}} \rightarrow 4 \%{ }^{\mathrm{C}}$ & [195] \\
\hline Humic acid (Peat) & $\begin{array}{c}\mathrm{Cd}^{2+} \\
(0.2 \mathrm{mg} / \mathrm{L})\end{array}$ & $0 \rightarrow 5 \mathrm{mg} / \mathrm{L}$ & $\begin{array}{c}\text { Pseudokirchneriella } \\
\text { subcapitata }\end{array}$ & $52 \%{ }^{\mathrm{A}} \rightarrow 8 \%{ }^{\mathrm{C}}$ & [195] \\
\hline Humic acid (Peat) & $\begin{array}{c}\mathrm{Zn}^{2+} \\
(0.39 \mathrm{mg} / \mathrm{L}) \\
\end{array}$ & $0 \rightarrow 5 \mathrm{mg} / \mathrm{L}$ & $\begin{array}{c}\text { Pseudokirchneriella } \\
\text { subcapitata }\end{array}$ & $55 \%^{\mathrm{A}} \rightarrow 30 \%{ }^{\mathrm{C}}$ & [195] \\
\hline Humic acid & $\begin{array}{c}\text { As(III) } \\
(100 \mu \mathrm{M})\end{array}$ & $0 \rightarrow 10 \mathrm{mg} / \mathrm{L}$ & $\begin{array}{c}\text { Stichococcus } \\
\text { bacillaris }\end{array}$ & $52 \%^{\mathrm{A}} \rightarrow 33 \%^{\mathrm{C}}$ & [141] \\
\hline $\begin{array}{l}\text { Humic acid } \\
\text { (Sediment) }\end{array}$ & $\begin{array}{c}\mathrm{Hg}^{2+} \\
(10 \mathrm{ppb})\end{array}$ & $0 \rightarrow 10 \mathrm{ppm}$ & Isochrysis galbana & $\begin{array}{l}\text { Complete } \\
\text { reduction in } \\
\text { growth inhibition } \\
\text { plus stimulation }\end{array}$ & [196] \\
\hline Humic acid & $\begin{array}{c}\mathrm{ZnO}-\mathrm{NPs} \\
(1 \mathrm{mg} / \mathrm{L})\end{array}$ & $0 \rightarrow 3 \mathrm{mg} / \mathrm{L}$ & Anabaena sp. & $70 \%{ }^{\mathrm{A}} \rightarrow 40 \%{ }^{\mathrm{C}}$ & [197] \\
\hline
\end{tabular}


Table 5. Cont.

\begin{tabular}{cccccc}
\hline Chelating Agent & Metal & $\begin{array}{c}\text { Uplift of } \\
\text { Chelating Agent } \\
\text { Concentration }\end{array}$ & Strain & $\begin{array}{c}\text { Reduction of } \\
\text { Growth } \\
\text { Inhibition }\end{array}$ & Reference \\
\hline $\begin{array}{c}\text { Fulvic acid } \\
\text { (Sediment) }\end{array}$ & $\begin{array}{c}\mathrm{Cu}^{2+} \\
(\sim 5 \mu \mathrm{M})\end{array}$ & $1 \rightarrow 5 \mathrm{mg} / \mathrm{L}$ & $\begin{array}{c}\text { Scenedesmus } \\
\text { subspicatus }\end{array}$ & $56 \%{ }^{\mathrm{Al}} \rightarrow 30 \%{ }^{\mathrm{C} 1}$ & {$[188]$} \\
\hline $\begin{array}{c}\text { Fulvic acid } \\
(\text { Suwannee River })\end{array}$ & $\begin{array}{c}\mathrm{Cd}^{2+} \\
(0.2 \mathrm{mg} / \mathrm{L})\end{array}$ & $0 \rightarrow 5 \mathrm{mg} / \mathrm{L}$ & $\begin{array}{c}\text { Pseudokirchneriella } \\
\text { subcapitata }\end{array}$ & $52 \%{ }^{\mathrm{A}} \rightarrow 45 \%{ }^{\mathrm{C}}$ & {$[195]$} \\
\hline $\begin{array}{c}\text { Fulvic acid } \\
\text { (Suwannee River) })\end{array}$ & $\begin{array}{c}\mathrm{Zn}^{2+} \\
(0.39 \mathrm{mg} / \mathrm{L})\end{array}$ & $0 \rightarrow 5 \mathrm{mg} / \mathrm{L}$ & $\begin{array}{c}\text { Pseudokirchneriella } \\
\text { subcapitata }\end{array}$ & $\begin{array}{c}\text { No reduction in } \\
\text { growth inhibition }\end{array}$ & {$[195]$} \\
\hline Fulvic acid (Soil) & $\mathrm{Al}{ }^{\mathrm{i}+\mathrm{o}}$ & $0 \rightarrow 11 \mathrm{mg} / \mathrm{L}$ & $\begin{array}{c}\text { Chlorella } \\
\text { pyrenoidosa }\end{array}$ & $\begin{array}{c}\text { Complete } \\
\text { reduction in } \\
\text { growth inhibition } \\
\text { plus stimulation }\end{array}$ & {$[202]$} \\
\hline
\end{tabular}

${ }^{\text {A }}$ growth inhibition in the absence of chelating agent; ${ }^{\mathrm{A} 1}$, growth inhibition in the presence of decreased amount of chelating agent; ${ }^{\mathrm{C}}$ growth inhibition in the presence of chelating agent; ${ }^{\mathrm{C}}$, growth inhibition in the presence of increased amount of chelating agent; ${ }^{i+o}$, a sum of inorganic and organic aluminum.

\subsubsection{Nanoparticles: Modulating Effect}

The presence of metallic and non-metallic nanomaterials can alter the effect of metals on microalgae. For instance, the presence of graphene oxide (GO) increased toxicity of Cd towards Microcystis aeruginosa [203], while Cd toxicity towards Chlamydomonas reinhardtii was reduced in the presence of titanium dioxide engineered nanoparticles (ENPs) [204]. $\mathrm{TiO}_{2}$ nanoparticles and $\mathrm{Zn}$ ions in the mixture exerted the enhanced or decreased toxicity towards Anabaena sp., depending on mutual interactions between different concentrations of $\mathrm{TiO}_{2}$ and $\mathrm{Zn}$ [73]. Finally, the presence of engineered nanoparticles was reported to decrease intracellular content of $\mathrm{Cu}$ and $\mathrm{Pb}$ in Chlorella kesslerii and wall-possessing Chlamydomonas reinhardtii, as metal binding to nanoparticles reduces availability of $\mathrm{Cu}$ and $\mathrm{Pb}$ to these microalgal strains [205].

\subsubsection{Macrocycles: Modulating Effect}

Supramolecular water soluble compounds such as cyclodextrins, calixarenes and resorcinarenes can possibly change interactions between microalgae and metals.

Cyclodextrins (CDs) are macrocyclic oligosaccharides composed of six, seven, or eight ( $\alpha$ 1-4) glucosidic units and called: $\alpha, \beta$ and $\gamma$-CDs, respectively. They are produced from enzymatic hydrolysis of starch, with cycloglycosyl transferase amylases (CGTases) [206,207]. CDs are ring molecules, either toroidal or cone shaped, but not cylindrical [208]. The primary hydroxyl groups are situated on the narrow side while, the secondary groups are located on the wider side. The central cavity of CDs is hydrophobic, while the outer part is hydrophilic due the presence of hydroxyl groups [209]. $\beta$-cyclodextrins can possess methyl, carboxymethyl or hydroxypropyl moieties [210,211] and form complexes with metals [212], phytosterols [213] and carotenoids [214]. Carboxymethyl- $\beta$-cyclodextrin $(3.3 \mathrm{mM})$ was successfully harnessed for reduction of metal $(\mathrm{Cd}, \mathrm{Co}, \mathrm{Cu})$ toxicity towards naphthalenedegrading bacterium Burkholderia sp. [215]. On the other hand, alhough hydroxypropyl- $\beta$-cyclodextrin 
up to $20 \mathrm{mM}$ did not itself cause inhibition of microalga Selenastrum capricornutum growth, it failed to protect this microalga strain against $\mathrm{Zn}$ toxicity [216], because hydroxypropyl- $\beta$-cyclodextrin does not possess metal-binding substituents [215].

Calix[ $n]$ arenes and resorcin[4] arenes are macrocyclic compounds consisting of phenol or resorcinol units, respectively, which are cyclically linked by aliphatic bridges [217]. Calix[ $n]$ arenes $(n=4,5,6$, 7 and 8 ) are obtained as a result of condensation of $p$-tert-butylphenol with formaldehyde under alkaline catalysis [218-220], whereas resorcin[4]arenes are formed as a result of acid-catalysed reaction between resorcinol and aliphatic or aromatic aldehydes [221]. Water-soluble calix[4]arenes and resorcin[4]arenes possess charged groups (ammonium, sulphonium, carboxylate, phosphate) or hydrophilic fragments [222-225]. Derivatives of calix[ $n]$ arenes such as $p$-sulphonate or methoxycarboxylic derivatives form stable complexes with $\mathrm{Zn}^{2+}, \mathrm{Cu}^{2+}, \mathrm{Ni}^{2+}$ under neutral or alkaline conditions [226-228]. Water soluble resorcin[4]arene derivatives are able to form complexes, not only with the metal ions, but also with amino acids, sugars, and nucleosides [229-231]. It was demonstrated that $p$-sulfonatocalix[4,6,8]arene and $C$-nonylresorcin[4]arene possess antimicrobial activity against fungal and bacterial microorganisms [232]. Additionally, $C$-methylcalix[4]-resorcinarene containing pyridinium salt, was reported to exhibit a selective inhibitory effect on Gram-positive bacteria [233].

Water soluble supramolecular molecules have the potential to modify interactions between metals and microorganisms such as microalgae, but their application in this field is highly unexplored.

\subsection{Development of Strain Tolerance to Metals}

Some microalgae are able to inhabit environments contaminated by heavy metals. Such microalgal strains possess uplifted tolerance towards heavy metals [104,234-237]. Increased tolerance can be also induced on laboratory scale by applying proper metal dosages [238,239] or metal-containing wastes [240]. It results in development of physiologically adapted strains [61,239,241] or metal resistant mutants due to rare spontaneous mutations that occur before metal treatment $[61,238,239]$. Microalgae with improved tolerance can become promising microbes for cultivation in metal polluted growth media and for production of target compounds [104]. However, it should be taken into consideration that increased tolerance can be strictly strain-metal specific [235] and a lack of inducing metal in the cultivation medium can have a negative effect on growth of metal resistant mutants [238].

\section{Strategy for Microalgal Production in the Presence of Metals}

It has been widely reported that microalgae cultures, due to their ability for metal accumulation, can be used for bioremediation of heavy metal contaminated water/wastewater streams [80,242,243]. In this review, other aspects of microalgae exposure to metals, such as production of numerous industrially important compounds from metal-exposed microalgae (Table 6) and stategies to alter microalga-metal interactions for industrial microalgae productions, are discussed. As a result of metal exposure, microalgae are able to synthesize a range of target compounds: pigments, lipids, peptides, exopolymers, phytohormones, arsenoorganics or nanomaterials, as a defense mechanism against metal stress. Although metals induce synthesis of compounds by microalgae cells, they may also have detrimental effects on cell number, growth rate, cell dry weight, thereby diminishing productivity of target compounds in a metal-trigger system. For instance, an elevated copper $(\mathrm{Cu})$ concentration increased 
chlorophyll and carotenoid content in Dunaliella cells [244] and stimulated release of polysaccharides from Cylindrotheca fusiformis [245] and phenolics from Dunaliella tertiolecta [246] cells, though at the expense of a reduced number of cells in the culture. In other studies, the content of chlorophyll, protein and lipids in Chlorella vulgaris [247], proline and total amino acids in Chlorella pyrenoidosa [63] and chlorophyll and carotenoid in Pseudokirchneriella subcapitata [248] increased in the presence of cadmium $(\mathrm{Cd})$, chromium $(\mathrm{Cr})$ and copper $(\mathrm{Cu})$ respectively, but the growth in these cultures was considerably suppressed [63,247,248]. A possible strategy to overcome this problem could be cultivation of microalgae under non-stressed conditions in order to obtain higher cells densities, with subsequent addition of metals for inducing stress and synthesis of target products in microalgae cells [10]. Metals at higher concentration are toxic to microalgae, but at lower concentration can be stimulatory for growth (Table 1). Additionaly, it was concluded that growth media might contain nutrients $(\mathrm{Ca}, \mathrm{Mg})$ in amounts that are not sufficient for some microalgal strains to achieve desirable growth [249] and therefore some metal-containing effluents could also serve as a nutrient replacement for $\mathrm{Ca}$ [41], $\mathrm{Fe}$ [37] or $\mathrm{Zn}$ [44] deficiency in growth media. Microalgae cultivation systems require large amounts of water [250] and production of target compounds with metal polluted industrial water streams, instead of exploiting clean water sources, could be an additional advantage. Growth of cyanobacteria Nostoc linckia and Nostoc rivularis was stimulated at low loadings of ( $\mathrm{Zn}, \mathrm{Cd}$ )-containing sewage waters, but suppressed at high sewage water loadings [251]. Industrial wastes/wastewaters contain not only metals, but also numerous organic pollutants (pesticides, pharmaceuticals, personal care products etc.) [252] that can be harmful for microalgae cultures. Furthermore, although metal uptake occurs in microalgal cultures, high dosage wastes can strongly decrease productivity of microalgal cultivation $[251,253]$. Therefore, precautions should be taken to control concentration of metals and/or organic toxicants, so that optimal microalgal growth and product biosynthesis could be obtained.

An integrated process for metal ( $\mathrm{Al}, \mathrm{Fe}, \mathrm{Mn}, \mathrm{Ba}, \mathrm{Ce}, \mathrm{La})$ remediation and lipid production in cultures of marine microalgae (Nannochloropsis, Pavlova, Tetraselmis, Chaetoceros) has already been proposed [254]. Recently, a combination of heavy metal ( $\mathrm{Zn}, \mathrm{Mn}, \mathrm{Cd}, \mathrm{Cu}$ ) removal to increase up to 2.17-fold lipid production from Chlorella minutissima has been described [115]. Further, it was concluded that small concentrations of metal mixtures (As, $\mathrm{Cd}, \mathrm{Co}, \mathrm{Cr}, \mathrm{Cu}, \mathrm{Hg}, \mathrm{Ni}, \mathrm{Pb}, \mathrm{Se}, \mathrm{Zn}$ ) present in coal fired flue gas could increase lipid yield in Scenedesmus obliquus cultures by $61 \%$ [255]. It was also suggested that uptake of lead $(\mathrm{Pb})$ from textile dyeing industry effluent by Neochloris sp. could be accompanied with accumulation of cell neutral lipid content with increased levels of oleic (C18:1) acid [256]. Additionally, metal exposure can lead to modifications in fatty acid profiles in microalgal cells, thereby improving quality of biodiesel [117]. Finally, the uptake of metals (Cr, Mn, Fe, Co, Ni, $\mathrm{Cu}, \mathrm{Mo}, \mathrm{Cd}, \mathrm{Pb}$ ) from landfill leachate combined with hydrogen production in Chlamydomonas reinhardtii cultures, has been discussed [257]. It should be noted that products, synthesized by microalgae cells in response to metal stress, can be contaminated by metals. The presence of metals in final products might not be appropriate in terms of application for food or medical purposes. Therefore, desorption methods (EDTA, diethyl dithiocarbamate, carbonate, dicarbonate) should be applied to obtain a metal free product, without causing the degradation of the product structure. Moreover, monitoring to maintain metal concentration in a final product below allowable thresholds must be considered.

Microalgae are capable of absorbing heavy metals under photoautotrophic [12,80,242,243] and heterotrophic conditions [234], and hence biocompound production under metal stress possibly could be 
achieved in open ponds, photobioreactors, but also in fermentation tanks [258]. Strictly controlled media compositions can modulate microalgal sensitivity towards heavy metals also during a chemostat-based continuous cultivation [59]. Additionally, an amount of microalgae biomass in relation to metal concentration should be taken into consideration, as high biomass densities can alleviate detrimental effect of metal ions on microalgae cells in culture [259,260]. The use of older culture inocullum also improved resistance of Scenedesmus quadricauda against Ag nanoparticles [239]. Synergistic effects of different heavy metal ions [261] or metal ions with nanoparticles (see Section 4.2.3) on microalgae cells, should be also taken into consideration. Additionally, although nanoparticles can be synthetized by microalgae cells (see Section 3.7), the presence of nanoparticles can have negative effects on microalgae (Table 1).

Composition of growth media and cultivation parameters have significant influence on microalgae resistance towards metal induced stress (see Chapter 4). Moreover, a modification of cultivation media with the change of metal concentration and/or composition can enhance not only growth, but also biosynthesis of target compounds. For instance, an alteration in $\mathrm{Fe}, \mathrm{Mn}$, Mo concentration and addition of $\mathrm{Ni}$, caused the increase in biomass and hydrocarbon productivity in Botryococcus braunii culture [262]. Also supplementation of growth medium for Chlorella vulgaris with $12 \mu \mathrm{M}$ chelated Fe ${ }^{3+}$, resulted in an increase in Chlorella cell number by $27 \%$ and lipid content by $625 \%$, when compared to the culture without $\mathrm{Fe}^{3+}$ added [263]. In another study, a six-fold uplift in $\mathrm{Fe}^{3+}$ concentration enabled an increase of $22 \%$ lipid productivity in Nannochloropsis oculata culture [264]. Anabaena variabilis, cultivated in a new vanadium $\left(\mathrm{VO}_{3}{ }^{-}\right)$-containing growth media, produced $550 \%$ more hydrogen, and $\mathrm{VO}_{3}{ }^{-}$was suggested as a microelement responsible for amplification of $\mathrm{H}_{2}$ synthesis [265]. Addition of $20 \mu \mathrm{g} / \mathrm{L} \mathrm{VO}_{3}{ }^{-}$into growth medium increased dry weight by up to $34 \%$, and cell chlorophyll content by up to $100 \%$ in heterotrophically cultivated Scenedesmus obliquus [37]. Further, $20 \mu \mathrm{g} / \mathrm{L} \mathrm{VO}_{3}{ }^{-}$stimulated production of zeaxanthin, lutein and $\beta$-carotene in Chlorella fusca cultivated at standard Fe medium concentration or Fe deficient conditions, and the stimulatory effect of $\mathrm{VO}_{3}{ }^{-}$was more pronounced at standard Fe concentration [266]. Vanadium, added as $1.25 \mathrm{mM} \mathrm{Na}_{3} \mathrm{VO}_{4}$ to Haematococcus lacustris culture, increased carotenoid synthesis in cells and carotenoid productivity in culture respectively by $120 \%$ and $25 \%$, after a two-day exposure. However, in a prolonged cultivation time, caronenoid productivity decreased drastically if compared to control, presumably due to inhibitory activity of $\mathrm{Na}_{3} \mathrm{VO}_{4}$ towards protein tyrosine phosphatase (PTPase) [39].

Supplementation of organic compounds into microalgal culture can be an additional protection in order to diminish interactions of metals from wastes to a level that enables metal-trigger production of target compounds, together with sufficient microalgal growth rate, even in high metal-level environment. Organic compounds such as phytohormones or various chelating agents inducing resistance mechanisms inside cells or creating a resistance barrier outside cells, can serve as a defense for cultivation of microalgae in high dose-metal contaminated systems. Interestingly, phytohormones can not only protect microalgae against metal stress [154,187], but can also improve growth [267] and increase the content of saturated [268] or unsaturated [267] fatty acids in microalgae cells. Therefore, a proper design of media composition (micro/macro-elements, phytohormones, chelating agents, macrocycles) and cultivation conditions $\left(\mathrm{CO}_{2}\right.$, light, temperature, $\left.\mathrm{pH}\right)$ seems to be necessary in order to avoid detrimental effects of heavy metal ions and to obtain sufficient growth and productivity of target compounds in metal-exposed microalgae cultures. Finally, microalgae strains isolated from heavy metal polluted areas 
or developed in the laboratory, are able to tolerate increased metal concentrations and can become promising candidates for cultivation under metal stress [104,235,236,240,241]. Such strains are more resistant against detrimental effects of metal exposure and could also be suitable for cultivation and synthesis of target products in outdoor open systems, as metal-stress conditions can prevent contamination by competitive or predatory micro and higher organisms [9,269].

Table 6. Some examples of metal effects on microalgae growth and bioproduct synthesis.

\begin{tabular}{|c|c|c|c|c|c|}
\hline $\begin{array}{c}\text { Microalgae } \\
\text { Strain } \\
\end{array}$ & Bioproduct & Metal/s & $\begin{array}{l}\text { Bioproduct } \\
\text { Synthesis Info }\end{array}$ & Growth & Reference \\
\hline \multicolumn{6}{|c|}{ Pigments } \\
\hline $\begin{array}{c}\text { Chlamydomonas } \\
\text { acidophilla }\end{array}$ & $\beta$-carotene & $\mathrm{Cu}^{2+} 0.1 \mathrm{~g} / \mathrm{L}$ & $120 \%$ increase & - & [103] \\
\hline \multirow{4}{*}{$\begin{array}{l}\text { Coccomyxa } \\
\text { onubensis }\end{array}$} & & $\mathrm{Fe}^{2+}$ & & & \multirow{4}{*}{ [104] } \\
\hline & Lutein & $0.5 \mathrm{mM}$ & $\sim 33 \%$ increase & $35 \%$ increase & \\
\hline & Zeaxanthin & $0.5 \mathrm{mM}$ & $\sim 93 \%$ increase & $35 \%$ increase & \\
\hline & $\beta$-carotene & $0.5 \mathrm{mM}$ & $\sim 35 \%$ increase & $35 \%$ increase & \\
\hline $\begin{array}{c}\text { Dunaliella } \\
\text { salina } \\
\end{array}$ & $\beta$-carotene & $\begin{array}{c}\mathrm{Fe}^{2+} \\
0 \rightarrow 450 \mu \mathrm{M}^{\mathrm{Ac}}\end{array}$ & 7-fold increase & $\begin{array}{c}\text { 4-fold } \\
\text { decrease }\end{array}$ & [105] \\
\hline \multirow{4}{*}{ Nostoc minutum } & & $\operatorname{As}(V)$ & & & \multirow{4}{*}[34]{} \\
\hline & Chlorophyll a & $0 \rightarrow 1000 \mathrm{mg} / \mathrm{L}$ & $75 \%$ increase & $66 \%$ increase & \\
\hline & Carotenoids & $0 \rightarrow 1000 \mathrm{mg} / \mathrm{L}$ & $40 \%$ increase & $66 \%$ increase & \\
\hline & Allophycocyanin & $0 \rightarrow 1000 \mathrm{mg} / \mathrm{L}$ & $24.7 \%$ increase & $66 \%$ increase & \\
\hline \multirow{3}{*}{ Anabaena doliolum } & & $\mathrm{Ni}^{2+}$ & & & \multirow{3}{*}{ [92] } \\
\hline & Chlorophyll a & $0 \rightarrow 10 \mu \mathrm{M}$ & $\sim 47 \%$ increase & $\begin{array}{c}35 \% \\
\text { increase }^{24 h}\end{array}$ & \\
\hline & C-phycocyanin & $0 \rightarrow 0.1 \mu \mathrm{M}$ & $\begin{array}{l}4.35 \text {-fold } \\
\text { increase }\end{array}$ & $\begin{array}{c}9 \% \\
\text { decrease }^{96 h} \\
\end{array}$ & \\
\hline \multirow{2}{*}{ Dunaliella salina } & Carotenoids & & $131 \%$ increase & & \multirow{4}{*}{ [244] } \\
\hline & Chlorophyll & & $62 \%$ increase & & \\
\hline Dunaliella & Carotenoids & $\begin{array}{c}\mathrm{Cu}^{2+} \\
1 \mu \mathrm{M} \rightarrow 20 \mu \mathrm{M}\end{array}$ & $\begin{array}{c}133 \% \\
\text { increase }\end{array}$ & $\begin{array}{c}>50 \% \\
\text { decrease }\end{array}$ & \\
\hline tertiolecta & Chlorophyll & & $\begin{array}{c}152 \% \\
\text { increase }\end{array}$ & & \\
\hline \multirow{4}{*}{$\begin{array}{c}\text { Pseudokirchneriella } \\
\text { subcapitata }\end{array}$} & Chlorophyll a & & 10.3 -fold & Decrease & \multirow{4}{*}{ [248] } \\
\hline & & $\mathrm{Cu}^{2+}$ & increase & $(20 \%$ in & \\
\hline & Chlorophyll b & $0.5 \rightarrow 60 \mu \mathrm{g} / \mathrm{L}$ & $\begin{array}{l}\text { 15.4-fold } \\
\text { increase }\end{array}$ & $\begin{array}{l}\text { growth rate } \\
\text { and } 72 \%\end{array}$ & \\
\hline & Carotenoids & & 4.1-fold increase & in biomass) & \\
\hline $\begin{array}{c}\text { Scenedesmus } \\
\text { obliquus }\end{array}$ & Chlorophyll & $\mathrm{VO}_{3}{ }^{-} 0 \rightarrow 20 \mu \mathrm{g} / \mathrm{L}$ & $100 \%$ increase & $34 \%$ increase & [37] \\
\hline
\end{tabular}


Table 6. Cont.

\begin{tabular}{|c|c|c|c|c|c|}
\hline $\begin{array}{c}\text { Microalgae } \\
\text { Strain } \\
\end{array}$ & Bioproduct & Metal/s & $\begin{array}{c}\text { Bioproduct } \\
\text { Synthesis Info }\end{array}$ & Growth & Reference \\
\hline Chlorella fusca & $\begin{array}{c}\text { Lutein } \\
\beta \text {-carotene } \\
\text { Zeaxanthin } \\
\end{array}$ & $\begin{array}{c}\mathrm{VO}_{3}^{-} 0 \rightarrow \\
20 \mu \mathrm{g} / \mathrm{L}^{\mathrm{SFeC}}\end{array}$ & $\begin{array}{l}18 \% \text { increase } \\
400 \% \text { increase } \\
130 \% \text { increase }\end{array}$ & - & [266] \\
\hline Chlorella fusca & $\begin{array}{c}\text { Lutein } \\
\beta \text {-carotene } \\
\text { Zeaxanthin } \\
\end{array}$ & $\begin{array}{c}\mathrm{VO}_{3}^{-}{ }^{-} 0 \rightarrow \\
20 \mu \mathrm{g} / \mathrm{L}^{\mathrm{FeDC}}\end{array}$ & $\begin{array}{c}17 \% \text { increase } \\
200 \% \text { increase } \\
40 \% \text { increase } \\
\end{array}$ & - & [266] \\
\hline $\begin{array}{c}\text { Haematococcus } \\
\text { lacustris }\end{array}$ & Carotenoids & $\begin{aligned} & \mathrm{VO}_{4}{ }^{3-} \\
& 0 \rightarrow 1.25 \mathrm{mM} \\
&\end{aligned}$ & $\begin{array}{c}125 \% \\
\text { increase }^{2 \mathrm{DE}} \\
\end{array}$ & $\begin{array}{c}45 \% \\
\text { decrease }^{2 \mathrm{DE}} \\
\end{array}$ & [39] \\
\hline $\begin{array}{c}\text { Haematococcus } \\
\text { lacustris }\end{array}$ & Carotenoids & $\begin{aligned} & \mathrm{VO}_{4}{ }^{3-} \\
& 0 \rightarrow 1.25 \mathrm{mM} \\
&\end{aligned}$ & No increase ${ }^{4 \mathrm{DE}}$ & $\begin{array}{c}40 \% \\
\text { decrease }^{4 \mathrm{DE}} \\
\end{array}$ & [39] \\
\hline $\begin{array}{c}\text { Chlorella } \\
\text { minutissima } \\
\end{array}$ & Lipids & 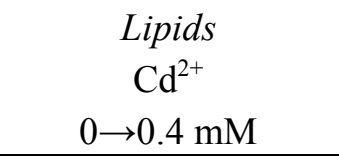 & $\sim 94 \%$ increase & $\begin{array}{c}\sim 12 \% \\
\text { increase }\end{array}$ & [115] \\
\hline Euglena gracilis & Lipids & $\underset{0 \rightarrow 1.3 \mu \mathrm{M}^{40 \%, 1}}{\mathrm{Cr}^{6+}}$ & $\begin{array}{c}44 \% \\
\text { increase }^{40 \%, 1}\end{array}$ & $\begin{array}{l}\mathrm{IC}_{50} \text { for } \\
3.2 \mu \mathrm{M}^{1}\end{array}$ & [116] \\
\hline Euglena gracilis & Lipids & $\underset{0 \rightarrow 9.84 \mu \mathrm{M}^{60 \%, 2}}{\mathrm{Cr}^{6+}}$ & $\begin{array}{c}28.5 \% \\
\text { increase }^{40 \%, 2}\end{array}$ & $\begin{array}{c}\mathrm{IC}_{50} \text { for } \\
24.6 \mu \mathrm{M}^{2}\end{array}$ & [116] \\
\hline Euglena gracilis & Lipids & $\begin{array}{c}\mathrm{Cr}^{6+} \\
0 \rightarrow 36.16 \mu \mathrm{M}^{40 \%, 3}\end{array}$ & $\begin{array}{c}100 \% \\
\text { increase } \\
\end{array}$ & $\begin{array}{c}\mathrm{IC}_{50} \text { for } \\
90.4 \mu \mathrm{M}^{3}\end{array}$ & [116] \\
\hline Euglena gracilis & Lipids & $\begin{array}{c}\mathrm{Cr}^{6+} \\
0 \rightarrow 48.2 \mu \mathrm{M}^{40 \%, 4}\end{array}$ & $\begin{array}{c}10 \% \\
\text { increase } \\
40 \%, 4\end{array}$ & $\begin{array}{c}\mathrm{IC}_{50} \text { for } \\
120.5 \mu \mathrm{M}^{4} \\
\end{array}$ & [116] \\
\hline Chlorella vulgaris & Lipids & $\begin{array}{l}\mathrm{TiO}_{2}-\mathrm{NPs} \\
0 \rightarrow 0.1 \mathrm{~g} / \mathrm{L}\end{array}$ & $10 \%$ increase & No change & {$[74]$} \\
\hline $\begin{array}{l}\text { Arthrospira } \\
\text { maxima } \\
\end{array}$ & Lipids & $\begin{array}{c}\text { nZVI-Nanofer } 25 \\
0 \rightarrow 5.1 \mathrm{mg} / \mathrm{L}\end{array}$ & $21 \%$ increase & $\begin{array}{c}15 \% \\
\text { increase }\end{array}$ & {$[57]$} \\
\hline $\begin{array}{c}\text { Desmodesmus } \\
\text { subspicatus }\end{array}$ & Lipids & $\begin{array}{c}\text { nZVI-Nanofer } 25 \\
0 \rightarrow 5.1 \mathrm{mg} / \mathrm{L}\end{array}$ & $58 \%$ increase & $\begin{array}{c}73 \% \\
\text { increase }\end{array}$ & {$[57]$} \\
\hline $\begin{array}{c}\text { Parachlorella } \\
\text { kessleri }\end{array}$ & Lipids & $\begin{array}{c}\text { nZVI-Nanofer } 25 \\
0 \rightarrow 5.1 \mathrm{mg} / \mathrm{L}\end{array}$ & $17 \%$ increase & $\begin{array}{c}41 \% \\
\text { increase } \\
\end{array}$ & [57] \\
\hline $\begin{array}{c}\text { Nannochloropsis } \\
\text { limnetica }\end{array}$ & $\begin{array}{l}\text { Eicosapentaenoic } \\
\text { acid C20:5 }\end{array}$ & $\begin{array}{c}\text { nZVI-Nanofer } 25 \\
0 \rightarrow 5.1 \mathrm{mg} / \mathrm{L}\end{array}$ & $58 \%$ increase & $\begin{array}{c}19 \% \\
\text { increase }\end{array}$ & [57] \\
\hline $\begin{array}{l}\text { Trachydiscus } \\
\text { minutus }\end{array}$ & $\begin{array}{c}\text { Eicosapentaenoic } \\
\text { acid C20:5 } \\
\end{array}$ & $\begin{array}{c}\text { nZVI-Nanofer } 25 \\
0 \rightarrow 5.1 \mathrm{mg} / \mathrm{L}\end{array}$ & $34 \%$ increase & $\begin{array}{c}31 \% \\
\text { increase } \\
\end{array}$ & {$[57]$} \\
\hline $\begin{array}{c}\text { Scenedesmus } \\
\text { obliquus }\end{array}$ & Lipids & $\begin{array}{c}(\mathrm{As}, \mathrm{Cd}, \mathrm{Co}, \mathrm{Cr}, \mathrm{Cu}, \\
\mathrm{Hg}, \mathrm{Ni}, \mathrm{Pb}, \mathrm{Se}, \mathrm{Zn}) \\
\text { as a mixture }\end{array}$ & $61 \%$ increase $^{1 x}$ & $\begin{array}{c}12 \% \\
\text { increase }^{1 x}\end{array}$ & [255] \\
\hline Neochloris sp. & $\begin{array}{l}\text { Oleic acid } \\
\text { C18:1 }\end{array}$ & $\begin{array}{l}\text { Effluent from textile } \\
\text { dyeing industry } \\
\text { containing } \mathrm{Pb}\end{array}$ & $\begin{array}{l}\text { Neutral lipid } \\
\text { accumulation } \\
\text { Oleic acid } \\
\text { accumulation }\end{array}$ & - & [256] \\
\hline
\end{tabular}


Table 6. Cont.

\begin{tabular}{|c|c|c|c|c|c|}
\hline $\begin{array}{c}\text { Microalgae } \\
\text { Strain } \\
\end{array}$ & Bioproduct & Metal/s & $\begin{array}{l}\text { Bioproduct } \\
\text { Synthesis Info }\end{array}$ & Growth & Reference \\
\hline $\begin{array}{c}\text { Chlorella } \\
\text { vulgaris }\end{array}$ & Lipids & $\begin{array}{c}\mathrm{Fe}^{3+} / \text { EDTA } \\
0 \rightarrow 12 \mu \mathrm{M} \\
\end{array}$ & 7.25 -fold increase & $\begin{array}{c}\sim 27 \% \\
\text { increase } \\
\end{array}$ & [263] \\
\hline $\begin{array}{c}\text { Nannochloropsis } \\
\text { oculata }\end{array}$ & Lipids & $\begin{array}{c}\mathrm{Fe}^{3++E D T A} 3.16 \rightarrow \\
18.96 \mathrm{mg} / \mathrm{L}\end{array}$ & $\begin{array}{c}22 \% \text { increase in } \\
\text { production }\end{array}$ & - & [264] \\
\hline Lyngbya putealis & $\begin{array}{c}\text { Exopolysaccharides } \\
\text { Exoproteins } \\
\end{array}$ & $\begin{array}{c}\text { Exopolymers } \\
\mathrm{Cu} \\
0 \rightarrow 2 \mathrm{mg} / \mathrm{L} \\
0 \rightarrow 2 \mathrm{mg} / \mathrm{L} \\
\end{array}$ & $\begin{array}{l}\text { 2.43-fold increase } \\
3.65 \text {-fold increase }\end{array}$ & $13 \%$ decrease & [131] \\
\hline Lyngbya putealis & $\begin{array}{c}\text { Exopolysaccharides } \\
\text { Exoproteins }\end{array}$ & $\begin{aligned} & \mathrm{Co} \\
& 0 \rightarrow 2 \mathrm{mg} / \mathrm{L} \\
& 0 \rightarrow 2 \mathrm{mg} / \mathrm{L}\end{aligned}$ & $\begin{array}{l}\text { 2.09-fold increase } \\
\text { 2.64-fold increase }\end{array}$ & $21 \%$ decrease & [131] \\
\hline $\begin{array}{c}\text { Thalassiosira } \\
\text { weissflogii }\end{array}$ & Polysaccharides EPF & $\mathrm{Ag}^{\mathrm{RENP}}$ & $\begin{array}{c}\sim 3.5 \text {-fold } \\
\text { increase }{ }^{\mathrm{NL}} \text { if: } \mathrm{Ag} \\
0.03 \rightarrow 0.11 \mathrm{nM}\end{array}$ & $\begin{array}{c}50 \% \\
\text { decrease } \\
\text { if: } \mathrm{Ag} \\
0.01 \mathrm{nM}\end{array}$ & [132] \\
\hline $\begin{array}{c}\text { Thalassiosira } \\
\text { weissflogii }\end{array}$ & Polysaccharides ${ }^{E P F}$ & $\mathrm{Ag}^{\text {RENP }}$ & $\begin{array}{c}\sim 6 \text {-fold } \\
\text { increase }{ }^{\mathrm{NE}} \text { if: } \mathrm{Ag} \\
0.01 \rightarrow 6.14 \mathrm{pM}\end{array}$ & $\begin{array}{c}50 \% \\
\text { decrease }^{\mathrm{NE}} \\
\text { if: } \mathrm{Ag} \\
2.16 \mathrm{pM} \\
\end{array}$ & [132] \\
\hline $\begin{array}{c}\text { Thalassiosira } \\
\text { pseudonana }\end{array}$ & Proteins ${ }^{E P F}$ & $\begin{array}{c}\mathrm{Cd}^{\text {RENP }} \\
0 \rightarrow 0.05 \mathrm{nM} \\
\end{array}$ & $\begin{array}{c}50 \% \\
\text { increase }^{\mathrm{CM}, \mathrm{NE}} \\
\end{array}$ & No change ${ }^{\mathrm{NE}}$ & [133] \\
\hline $\begin{array}{c}\text { Thalassiosira } \\
\text { pseudonana }\end{array}$ & Carbohydrates ${ }^{\text {EPF }}$ & $\begin{array}{c}\mathrm{Cd}^{\text {RENP }} \\
0 \rightarrow 0.05 \mathrm{nM} \\
\end{array}$ & $\begin{array}{c}\text { 2-fold } \\
\text { increase }^{\mathrm{CM}, \mathrm{NE}}\end{array}$ & No change ${ }^{N E}$ & [133] \\
\hline $\begin{array}{l}\text { Cylindrotheca } \\
\text { fusiformis }\end{array}$ & Exopolysaccharides & $\begin{array}{c}\mathrm{Cu}^{2+} \\
0 \rightarrow 0.5 \mathrm{mg} / \mathrm{L}\end{array}$ & $100 \%$ increase ${ }^{\mathrm{RC}}$ & $57 \%$ decrease & {$[245]$} \\
\hline $\begin{array}{l}\text { Chlorella } \\
\text { vulgaris }\end{array}$ & Indole-acetic acid & $\begin{array}{c}\text { Phytohormones } \\
\qquad \begin{array}{c}\mathrm{Cd} \\
0 \rightarrow 10^{-4} \mathrm{M}\end{array} \\
0 \rightarrow 10^{-4} \mathrm{M}^{+\mathrm{B}}\end{array}$ & $\begin{array}{c}\sim 147 \% \text { increase }^{\mathrm{Ct}} \\
3.6 \text {-fold } \\
\text { increase }^{\mathrm{Ct}} \\
\end{array}$ & $\begin{array}{c}\sim 35 \% \\
\text { decrease }^{\mathrm{Ct}} \\
\sim 8 \% \\
\text { decrease }^{\mathrm{Ct}} \\
\end{array}$ & [154] \\
\hline $\begin{array}{l}\text { Chlorella } \\
\text { vulgaris }\end{array}$ & Zeatin & $\begin{array}{c}\mathrm{Pb} \\
0 \rightarrow 10^{-4} \mathrm{M} \\
0 \rightarrow 10^{-4} \mathrm{M}^{+\mathrm{B}}\end{array}$ & $\begin{array}{l}\sim 35 \% \text { increase }^{\mathrm{Ct}} \\
\sim 85 \% \text { increase }^{\mathrm{Ct}}\end{array}$ & $\begin{array}{c}\sim 40 \% \\
\text { decrease }^{\mathrm{Ct}} \\
\sim 16 \% \\
\text { decrease }^{\mathrm{Ct}} \\
\end{array}$ & {$[154]$} \\
\hline $\begin{array}{l}\text { Chlorella } \\
\text { vulgaris }\end{array}$ & Abscisic acid & $\begin{array}{c}\mathrm{Cu} \\
0 \rightarrow 10^{-4} \mathrm{M} \\
0 \rightarrow 10^{-4} \mathrm{M}^{+\mathrm{B}}\end{array}$ & $\begin{array}{l}\sim 45 \% \text { increase }^{\mathrm{Ct}} \\
\sim 65 \% \text { increase }^{\mathrm{Ct}} \\
\end{array}$ & $\begin{array}{c}\sim 45 \% \\
\text { decrease }^{\mathrm{Ct}} \\
\sim 24 \% \\
\text { decrease }^{\mathrm{Ct}} \\
\end{array}$ & [154] \\
\hline
\end{tabular}


Table 6. Cont.

\begin{tabular}{|c|c|c|c|c|c|}
\hline $\begin{array}{c}\text { Microalgae } \\
\text { Strain } \\
\end{array}$ & Bioproduct & Metal/s & $\begin{array}{l}\text { Bioproduct } \\
\text { Synthesis Info }\end{array}$ & Growth & Reference \\
\hline $\begin{array}{c}\text { Chlamydomonas } \\
\text { reinhardtii }\end{array}$ & $\mathrm{H}_{2}$ & $\begin{array}{c}\text { Hydrogen } \\
16 \% \text { leachate } \\
\text { medium containing: } \\
(\mathrm{Cr}, \mathrm{Mn}, \mathrm{Fe}, \mathrm{Co}, \\
\mathrm{Ni}, \mathrm{Cu}, \mathrm{Mo}, \mathrm{Cd}, \mathrm{Pb})\end{array}$ & $\sim 37 \%$ increase & $\sim 50 \%$ increase & [257] \\
\hline $\begin{array}{l}\text { Anabaena } \\
\text { variabilis }\end{array}$ & $\mathrm{H}_{2}$ & $\begin{array}{c}\mathrm{VO}_{3}^{-} \\
0 \rightarrow 0.023 \mathrm{mg} / \mathrm{L}^{\mathrm{M}}\end{array}$ & 5.5-fold increase & $\begin{array}{l}\text { Delayed }^{\text {FSC }} \\
\text { No change in } \\
\text { growth }\end{array}$ & [265] \\
\hline $\begin{array}{l}\text { Dunaliella } \\
\text { tertiolecta }\end{array}$ & Phenolics & $\begin{array}{l}\text { Other products } \\
\qquad \mathrm{Cu}^{2+} \\
0 \rightarrow 0.79 \mu \mathrm{M}\end{array}$ & $40 \%$ increase $^{\mathrm{RC}}$ & $34 \%$ decrease & [246] \\
\hline $\begin{array}{c}\text { Chlorella } \\
\text { vulgaris }\end{array}$ & $\begin{array}{c}\text { Chlorophyll a } \\
\text { Protein } \\
\text { Lipids } \\
\end{array}$ & $\begin{array}{c}\mathrm{Cd}^{2+} \\
0 \rightarrow 0.1 \mu \mathrm{mol} / \mathrm{L}\end{array}$ & $\begin{array}{l}\sim 4 \text {-fold increase } \\
\sim 5 \text {-fold increase } \\
\sim 3 \text {-fold increase }\end{array}$ & $\sim 65 \%$ decrease & [247] \\
\hline $\begin{array}{c}\text { Chlorella } \\
\text { pyrenoidosa }\end{array}$ & $\begin{array}{l}\text { Proline Total } \\
\text { Amino Acids }\end{array}$ & $\begin{array}{c}\mathrm{Cr}^{6+} \\
0 \rightarrow 5 \mathrm{mg} / \mathrm{L} \\
\end{array}$ & $\begin{array}{l}240 \% \text { increase } \\
66 \% \text { increase }\end{array}$ & $60 \%$ decrease & {$[63]$} \\
\hline $\begin{array}{c}\text { Botryococcus } \\
\text { braunii }\end{array}$ & Hydrocarbons & $\begin{array}{l}\text { Modifications of } \\
\text { culture media } \\
\text { composition }\end{array}$ & $\begin{array}{c}27 \% \text { increase } \\
\text { after: Fe and Mn } \\
\text { uplift }+\mathrm{Mo} \\
\text { decrease }+\mathrm{Ni} \\
\text { addition } \\
(1.73 \mu \mathrm{M})\end{array}$ & $\begin{array}{c}34 \% \text { increase } \\
\text { after: Fe and } \\
\text { Mn decrease }+ \\
\text { Mo uplift }+\mathrm{Ni} \\
\text { addition } \\
(3.38 \mu \mathrm{M})\end{array}$ & [262] \\
\hline
\end{tabular}

Info, product synthesis expressed on various basis (cell content, dry weight, release from cells, concentration in the culture, productivity); ${ }^{\mathrm{Ac}}$, with $67.5 \mathrm{mM}$ acetate; ${ }^{24 \mathrm{~h}}$, a $24 \mathrm{~h}$ cultivation time; ${ }^{96 \mathrm{~h}}$, a $96 \mathrm{~h}$ cultivation time; ${ }^{\mathrm{SFeC}}$, standard Fe concentration; ${ }^{\mathrm{FeDC}}$, Fe deficient conditions; ${ }^{2 \mathrm{DE}}$, increase in cells after a 2-day exposure and compared to control cells at the same cultivation time; ${ }^{4 \mathrm{DE}}$, increase in cells after a 4-day exposure and compared to control cells at the same cultivation time; $40 \%$, concentration that constitutes $40 \%$ of a concentration necessary to obtain $\mathrm{IC}_{50} ;{ }^{1}$, a UTEX strain cultivated in Buetow medium; ${ }^{2}$, a MAT strain cultivated in Buetow medium; ${ }^{3}$, a UTEX strain cultivated in C\&M medium; ${ }^{4}$, a MAT strain cultivated in C\&M medium; ${ }^{1 \mathrm{x}}$, for a lowest metal mixture tested; ${ }^{\mathrm{Ut}}, \mathrm{Pb}$ was partially utilized by strain; ${ }^{+\mathrm{EDTA}}$, a six fold increase in EDTA concentration also suggested; ${ }^{\text {EPF }}$, from Extracellular Polymeric Fraction; ${ }^{\text {RENP }}$, released from Engineered Nanoparticles; ${ }^{\mathrm{NL}}$, nitrogen limited medium; ${ }^{\mathrm{NE}}$, nutrient enriched medium; ${ }^{\mathrm{CM}}$, in cultivation media; ${ }^{\mathrm{RC}}$, the release from cells; ${ }^{+\mathrm{B}}$, plus brassinolide $10^{-8} \mathrm{M}$; ${ }^{\mathrm{Ct}}$, when compared to control without heavy metal and brassinolide; ${ }^{\mathrm{M}}$, composition and concentration of other micro/macro nutrients also changed; ${ }^{\mathrm{FSC}}$, during the first stage of cultivation; ${ }^{\mathrm{PCT}}$, in prolonged cultivation time.

\section{Summary}

Metal exposure can be an interesting method to induce, in microalgae cells, the synthesis of target products such as pigments, lipids, peptides, exopolymers, phytohormones, arsenoorganics and nanoparticles. However, stimulation of target compound production in microalgae depends on many factors such as metal type and concentration or metal combination leading to synergistic effects, specificity of strain and cultivation parameters, and growth media composition, which all taken together 
determines the outcome of microalga response towards metal stress. Moreover, microalgae cultivation under stress conditions can stimulate production of target compounds, but usually at the expense of decreased growth rates, that diminishes overall productivity of metal exposed microalgae systems. The exception are resistant strains isolated from metal contaminated environments. A combination of metal removal from contaminated wastewaters, with metal-induced product biosynthesis, can be applied. Moreover, metal-containing wastewaters could also serve as a replenishment for microalgae growth in nutrient-deficient media. Suitable dosages of metals in relation to selected microalgae strain and adjusted growth conditions is key to develop efficient metal-exposed microalgal production systems.

\section{Acknowledgments}

This work was financed by AgricultureIsLife Platform at University of Liege-Gembloux Agro-Bio Tech.

\section{Author Contributions}

Krystian Miazek conducted literature research and wrote manuscript. Waldemar Iwanek wrote a part of manuscript concerning macrocycles. Claire Remacle provided expertise concerning metal uptake, oxidative stress and enzymatic reactions. Aurore Richel provided expertise in organometallic chemistry. Dorothee Goffin provided expertise in industrial applications of various products from microalgae. Additionally, Claire Remacle, Aurore Richel and Dorothee Goffin provided valuable comments, suggestions and corrections during the whole process of manuscript preparation.

\section{Conflicts of Interest}

The authors declare no conflict of interest.

\section{References}

1. Leliaert, F.; Smith, D.R.; Moreau, H.; Herron, M.D.; Verbruggen, H.; Delwiche, C.F.; de Clerck, O. Phylogeny and molecular evolution of the green algae. CRC Crit. Rev. Plant Sci. 2012, 31, 1-46.

2. Scott, J.L.; Baca, B.; Ott, F.D.; West, J.A. Light and electron microscopic observations on Erythrolobus coxiae gen.et sp. nov. (Porphyrideophyceae, Rhodophyta) from Texas U.S.A. Algae 2006, 21, 407-416.

3. Mann, D.G. The species concept in diatoms. Phycologia 1999, 38, 437-495.

4. Hackett, J.D.; Anderson, D.M.; Erdner, D.L.; Bhattacharya, D. Dinoflagellates: A remarkable evolutionary experiment. Am. J. Bot. 2004, 91, 1523-1534.

5. Komarek, J. Cyanobacterial taxonomy: Current problems and prospects for the integration of traditional and molecular approaches. Algae 2006, 21, 349-375.

6. Lowrey, J.; Brooks, M.S.; McGinn, P.J. Heterotrophic and mixotrophic cultivation of microalgae for biodiesel production in agricultural wastewaters and associated challenges-A critical review. J. Appl. Phycol. 2015, 27, 1485-1498. 
7. Shukla, S.P.; Kviderova, J.; Triska, J.; Elster, J. Chlorella mirabilis as a potential species for biomass production in low-temperature environment. Front. Microbiol. 2013, 4, 97.

8. Bleeke, F.; Rwehumbiza, V.M.; Winckelmann, D.; Klöck, G. Isolation and characterization of new temperature tolerant microalgal strains for biomass production. Energies 2014, 7, 7847-7856.

9. Varshney, P.; Mikulic, P.; Vonshak, A.; Beardall, J.; Wangikar, P.P. Extremophilic micro-algae and their potential contribution in biotechnology. Bioresour. Technol. 2015, 184, 363-372.

10. Markou, G.; Nerantzis, E. Microalgae for high-value compounds and biofuels production: A review with focus on cultivation under stress conditions. Biotechnol. Adv. 2013, 31, 1532-1542.

11. Tangahu, B.V.; Abdullah, S.R.S.; Basri, H.; Idris, M.; Anuar, N.; Mukhlisin, M. A review on heavy metals $(\mathrm{As}, \mathrm{Pb}$, and $\mathrm{Hg}$ ) uptake by plants through phytoremediation. Int. J. Chem. Eng. 2011, doi:10.1155/2011/939161.

12. Monteiro, C.M.; Castro, P.M.L.; Malcata, F.X. Metal uptake by microalgae: Underlying mechanisms and practical applications. Biotechnol. Prog. 2012, 28, 299-311.

13. Von Moos, N.; Slaveykova, V.I. Oxidative stress induced by inorganic nanoparticles in bacteria and aquatic microalgae - State of the art and knowledge gaps. Nanotoxicology 2013, 1-26.

14. Klaine, S.J.; Alvarez, P.J.J.; Batley, G.E.; Fernandes, T.F.; Handy, R.D.; Lyon, D.Y.; Mahendra, S.; McLaughlin, M.J.; Lead, J.R. Nanomaterials in the environment: Behavior, fate, bioavailability, and effects. Environ. Toxicol. Chem. 2008, 27, 1825-1851.

15. Gonzalez, V.; Vignati, D.A.L.; Leyval, C.; Giamberini, L. Environmental fate and ecotoxicity of lanthanides: Are they a uniform group beyond chemistry? Environ. Int. 2014, 71, 148-157.

16. Aral, H.; Vecchio-Sadus, A. Toxicity of lithium to humans and the environment-A literature review. Ecotoxicol. Environ. Saf. 2008, 70, 349-356.

17. Andersen, R.A. Algal Culturing Techniques; Elsevier Academic Press: San Diego, CA, USA, 2005; ISBN 978-0-12-088426-1.

18. Moroney, J.V.; Bartlett, S.G.; Samuelsson, G. Carbonic anhydrases in plants and algae. Plant Cell Environ. 2001, 24, 141-153.

19. Sunda, W.G. Feedback interactions between trace metal nutrients and phytoplankton in the ocean. Front. Microbiol. 2012, doi:10.3389/fmicb.2012.00204.

20. Bothe, H.; Schmitz, O.; Yates, M.G.; Newton, W.E. Nitrogen fixation and hydrogen metabolism in cyanobacteria. Microbiol. Mol. Biol. Rev. 2010, 74, 529-551.

21. Vega, J.M.; Herrera, J.; Aparicio, P.J.; Paneque, A.; Losada, M. Role of molybdenum in nitrate reduction by Chlorella. Plant Physiol. 1971, 48, 294-299.

22. Nishikawa, K.; Yamakoshi, Y.; Uemura, I.; Tominaga, N. Ultrastructural changes in Chlamydomonas acidophila (Chlorophyta) induced by heavy metals and polyphosphate metabolism. FEMS Microbiol. Ecol. 2003, 44, 253-259.

23. Carfagna, S.; Lanza, N.; Salbitani, G.; Basile, A.; Sorbo, S.; Vona, V. Physiological and morphological responses of lead and cadmium exposed Chlorella sorokiniana 211-8K (Chlorophyceae). Springerplus 2013, 2, 147.

24. Aoki, M.; Matsumoto, H.; Takahashi, T.; Sato, K.; Kumata, H.; Fujiwara, K. Thallium Induces Morphological Changes in the Photosynthetic Apparatus of Synechocystis sp. PCC6803; In Photosynthesis: Research for Food, Fuel and Future-15th International Conference on Photosynthesis; Zhejiang University Press: Hangzhou, China, 2013; pp. 586-589. 
25. Andosch, A.; Hoftberger, M.; Lutz, C.; Lutz-Meindl, U. Subcellular sequestration and impact of heavy metals on the ultrastructure and physiology of the multicellular freshwater alga Desmidium swartzii. Int. J. Mol. Sci. 2015, 16, 10389-10410.

26. Sacan, M.T.; Oztay, F.; Bolkent, S. Exposure of Dunaliella tertiolecta to lead and aluminum: Toxicity and effects on ultrastructure. Biol. Trace Elem. Res. 2007, 120, 264-272.

27. Yingjun, W.; Jia, L.; Yun, L.; Hangbiao, J.; Shihuai, D.; Yunmin, Z. Effects of cerium on growth and physiological characteristics of Anabaena flosaquae. J. Rare Earths 2012, 30, 1287-1292.

28. Periz, G.; Dharia, D.; Miller, S.H.; Keller, L.R. Flagellar elongation and gene expression in Chlamydomonas reinhardtii. Eukaryot. Cell 2007, 6, 1411-1420.

29. Nordi, C.S.F.; Cavagliere, T.G.W.F.; Vieira, A.A.H.; Nascimento, O.R. Efeito caotrópico do íon lítio na permeabilidade da cápsula polissacarídica da microalga Ankistrodesmus gracilis (Reinsch) Korsikov (Chlorophyceae). Acta Bot. Bras. 2006, 20, 449-454.

30. Karlander, E.P.; Krauss, R.W. Absorption and toxicity of beryllium and lithium in Chlorella vannielii Shihira and Krauss. Chesap. Sci. 1972, 13, 245-253.

31. Mota, R.; Pereira, S.B.; Meazzini, M.; Fernandes, R.; Santos, A.; Evans, C.A.; de Philippis, R.; Wright, P.C.; Tamagnini, P. Effects of heavy metals on Cyanothece sp. CCY 0110 growth, extracellular polymeric substances (EPS) production, ultrastructure and protein profiles. J. Proteom. 2015, 120, 75-94.

32. Basharina, T.N.; Danilovtseva, E.N.; Zelinskiy, S.N.; Klimenkov, I.V.; Likhoshway, Y.V.; Annenkov, V.V. The effect of titanium, zirconium and tin on the growth of diatom Synedra acus and morphology of its silica valves. Silicon 2012, 4, 239-249.

33. El-Sheekh, M.M.; el-Naggar, A.H.; Osman, M.E.H.; el-Mazaly, E. Effect of cobalt on growth, pigments and the photosynthetic electron transport in Monoraphidium minutum and Nitzchia perminuta. Braz. J. Plant Physiol. 2003, 15, 159-166.

34. Ferrari, S.G.; Silva, P.G.; Gonzalez, D.M.; Navoni, J.A.; Silva, H.J. Arsenic tolerance of cyanobacterial strains with potential use in biotechnology. Rev. Argent. Microbiol. 2013, 45, 174-179.

35. Karadjova, I.B.; Slaveykova, V.I.; Tsalev, D.L. The biouptake and toxicity of arsenic species on the green microalga Chlorella salina in seawater. Aquat. Toxicol. 2008, 87, 264-271.

36. Knauer, K.; Hemond, H. Accumulation and reduction of arsenate by the freshwater green alga Chlorella sp. (Chlorophyta). J. Phycol. 2000, 36, 506-509.

37. Meisch, H.U.; Bielig, H.J. Effect of vanadium on growth, chlorophyll formation and iron metabolism in unicellular green algae. Arch. Microbiol. 1975, 105, 77-82.

38. Meisch, H.U.; Benzschawel, H.; Bielig, H.J. The role of vanadium in green plants. Arch. Microbiol. 1977, 114, 67-70.

39. Tran, N.P.; Park, J.K.; Kim, Z.H.; Lee, C.G. Influence of sodium orthovanadate on the production of astaxanthin from green algae Haematococcus lacustris. Biotechnol. Bioprocess Eng. 2009, 14, 322-329.

40. Fargasova, A.; Bumbalova, A.; Havranek, E. Ecotoxicological effects and uptake of metals $\left(\mathrm{Cu}^{+}\right.$, $\left.\mathrm{Cu}^{2+}, \mathrm{Mn}^{2+}, \mathrm{Mo}^{6+}, \mathrm{Ni}^{2+}, \mathrm{V}^{5+}\right)$ in freshwater alga Scenedesmus quadricauda. Chemosphere 1999, $38,1165-1173$. 
41. Goecke, F.; Jerez, C.G.; Zachleder, V.; Figueroa, F.L.; Rezanka, T.; Bisova, K.; Vitova, M. Use of lanthanides to alleviate the effects of metal ion-deficiency in Desmodesmus quadricauda (Sphaeropleales, Chlorophyta). Front. Microbiol. 2015, 6, 2.

42. Jin, X.; Chu, Z.; Yan, F.; Zeng, Q. Effects of lanthanum(III) and EDTA on the growth and competition of Microcystis aeruginosa and Scenedesmus quadricauda. Limnologica 2009, 39, 86-93.

43. Tai, P.; Zhao, Q.; Su, D.; Li, P.; Stagnitti, F. Biological toxicity of lanthanide elements on algae. Chemosphere 2010, 80, 1031-1035.

44. Lee, J.G.; Roberts, S.B.; Morel, F.M.M. Cadmium: A nutrient for the marine diatom Thalassiosira weissflogii. Limnol. Oceanogr. 1995, 40, 1056-1063.

45. Alterio, V.; Langella, E.; de Simone, G.; Monti, S.M. Cadmium-containing carbonic anhydrase CDCA1 in marine diatom Thalassiosira weissflogii. Mar. Drugs 2015, 13, 1688-1697.

46. Rees, T.A.V., Bekheet, I.A. The role of nickel in urea assimilation by algae. Planta 1982, 156, $385-387$.

47. Oliveira, L.; Antia, N.J. Evidence of nickel ion requirement for autotrophic growth of a marine diatom with urea serving as nitrogen source. Br. Phycol. J. 1984, 19, 125-134.

48. Egleston, E.S.; Morel, F.M.M. Nickel limitation and zinc toxicity in a urea-grown diatom. Limnol. Oceanogr. 2008, 53, 2462-2471.

49. Xia, B.; Chen, B.; Sun, X.; Qu, K.; Ma, F.; Du, M. Interaction of $\mathrm{TiO}_{2}$ nanoparticles with the marine microalga Nitzschia closterium: Growth inhibition, oxidative stress and internalization. Sci. Total Environ. 2015, 508, 525-533.

50. Suman, T.Y.; Rajasree, S.R.R.; Kirubagaran, R. Evaluation of zinc oxide nanoparticles toxicity on marine algae Chlorella vulgaris through flow cytometric, cytotoxicity and oxidative stress analysis. Ecotoxicol. Environ. Saf. 2015, 113, 23-30.

51. Castro-Bugallo, A.; Gonzalez-Fernandez, A.; Guisande, C.; Barreiro, A. Comparative responses to metal oxide nanoparticles in marine phytoplankton. Arch. Environ. Contam. Toxicol. 2014, 67, 483-493.

52. Lee, W.M.; An, Y.J. Effects of zinc oxide and titanium dioxide nanoparticles on green algae under visible, UVA, and UVB irradiations: No evidence of enhanced algal toxicity under UV pre-irradiation. Chemosphere 2013, 91, 536-544.

53. Aravantinou, A.F.; Tsarpali, V.; Dailianis, S.; Manariotis, I.D. Effect of cultivation media on the toxicity of $\mathrm{ZnO}$ nanoparticles to freshwater and marine microalgae. Ecotoxicol. Environ. Saf. 2015, 114, 109-116.

54. Sadiq, I.M.; Pakrashi, S.; Chandrasekaran, N.; Mukherjee, A. Studies on toxicity of aluminum oxide $\left(\mathrm{Al}_{2} \mathrm{O}_{3}\right)$ nanoparticles to microalgae species: Scenedesmus sp. and Chlorella sp. J. Nanopart. Res. 2011, 13, 3287-3299.

55. Manier, N.; Bado-Nilles, A.; Delalain, P.; Aguerre-Chariol, O.; Pandard, P. Ecotoxicity of non-aged and aged $\mathrm{CeO}_{2}$ nanomaterials towards freshwater microalgae. Environ. Pollut. 2013, 180, 63-70.

56. Manzo, S.; Miglietta, M.L.; Rametta, G.; Buono, S.; Francia, G.D. Toxic effects of ZnO nanoparticles towards marine algae Dunaliella tertiolecta. Sci. Total Environ. 2013, 445-446, $371-376$. 
57. Padrova, K.; Lukavsky, J.; Nedbalova, L.; Cejkova, A.; Cajthaml, T.; Sigler, K.; Vitova, M.; Rezanka, T. Trace concentrations of iron nanoparticles cause overproduction of biomass and lipids during cultivation of cyanobacteria and microalgae. J. Appl. Phycol. 2015, 27, 1443-1451.

58. Capolino, E.; Tredici, M.; Pepi, M.; Baldi, F. Tolerance to mercury chloride in Scenedesmus strains. BioMetals 1997, 10, 85-94.

59. Chen, C.Y.; Lin, K.C. Optimization and performance evaluation of the continuous algal toxicity test. Environ. Toxicol. Chem. 1997, 16, 1337-1344.

60. Gissi, F.; Adams, M.S.; King, C.K.; Jolley, D.F. Robust bioassay to assess the toxicity of metals to the Antarctic marine microalga Phaeocyctis antarctica. Environ. Toxicol. Chem. 2015, doi:10.1002/etc.2949.

61. D’ors, A.; Pereira, M.; Bartolome, M.C.; Lopez-Rodas, V.; Costas, E.; Sanchez-Fortun, S. Toxic effects and specific chromium acquired resistance in selected strains of Dyctiosphaerium chlorelloides. Chemosphere 2010, 81, 282-287.

62. Millach, L.; Sole, A.; Esteve, I. Role of Geitlerinema sp. DE2011 and Scenedesmus sp. DE2009 as bioindicators and immobilizers of chromium in a contaminated natural environment. Biomed. Res. Int. 2015, doi:10.1155/2015/519769.

63. Hörcsik, Z.; Oláh, V.; Balogh, A.; Mészáros, I.; Simon, L.; Lakatos, G. Effect of Chromium(VI) on growth, element and photosynthetic pigment composition of Chlorella pyrenoidosa. Acta Biol. Szeged. 2006, 50, 19-23.

64. Ouyang, H.L.; Kong, X.Z.; He, W.; Qin, N.; He, Q.S.; Wang, Y.; Wang, R.; Xu, F.L. Effects of five heavy metals at sub-lethal concentrations on the growth and photosynthesis of Chlorella vulgaris. Chin. Sci. Bull. 2012, 57, 3363-3370.

65. Levy, J.L.; Stauber, J.L.; Adams, M.S.; Maher, W.A.; Kirby, J.K.; Jolley, D.F. Toxicity, biotransformation, and mode of action of arsenic in two freshwater microalgae (Chlorella $\mathrm{sp}$. and Monoraphidium arcuatum). Environ. Toxicol. Chem. 2005, 24, 2630-2639.

66. Rahman, M.A.; Hogan, B.; Duncan, E.; Doyle, C.; Krassoi, R.; Rahman, M.M.; Naidu, R.; Lim, R.P.; Maher, W.; Hassler, C. Toxicity of arsenic species to three freshwater organisms and biotransformation of inorganic arsenic by freshwater phytoplankton (Chlorella sp. CE-35). Ecotoxicol. Environ. Saf. 2014, 106, 126-135.

67. Huang, W.J.; Wu, C.C.; Chang, W.C. Bioaccumulation and toxicity of arsenic in cyanobacteria cultures separated from a eutrophic reservoir. Environ. Monit. Assess. 2014, 186, 805-814.

68. Trenfield, M.A.; van Dam, J.W.; Harford, A.J.; Parry, D.; Streten, C.; Gibb, K.; van Dam, R.A. Aluminium, gallium and molybdenum toxicity to the tropical marine microalga Isochrysis galbana. Environ. Toxicol. Chem. 2015, doi:10.1002/etc.2996.

69. Bascik-Remisiewicz, A.; Tukaj, Z. Toxicity of inorganic cadmium salts to the microalga Scenedesmus armatus (Chiorophyta) with respect to medium composition, $\mathrm{pH}$ and $\mathrm{CO}_{2}$ concentration. Acta Physiol. Plant. 2002, 24, 59-65.

70. Nohomovich, B.; Nguyen, B.T.; Quintanilla, M.; Lee, L.H.; Murray, S.R.; Chu, T.C. Physiological effects of nickel chloride on the freshwater cyanobacterium Synechococcus sp. IU 625. Adv. Biosci. Biotechnol. 2013, 4, 10-14. 
71. Hassler, C.S.; Chafin, R.D.; Klinger, M.B.; Twiss, M.R. Application of the biotic ligand model to explain potassium interaction with thallium uptake and toxicity to plankton. Environ. Toxicol. Chem. 2007, 26, 1139-1145.

72. Aoki, M.; Suematsu, H.; Kumata, H.; Fujiwara, K. Physiological and photosynthetic toxicity of thallium in Synechocystis sp. PCC6803. In Photosynthesis. Energy from the Sun: 14th International Congress on Photosynthesis; Springer: Berlin, Germany, 2008; pp. 1399-1402.

73. Tang, Y.; Li, S.; Qiao, J.; Wang, H.; Li, L. Synergistic effects of nano-sized titanium dioxide and zinc on the photosynthetic capacity and survival of Anabaena sp. Int. J. Mol. Sci. 2013, 14, 14395-14407.

74. Kang, N.K.; Lee, B.; Choi, G.G.; Moon, M.; Park, M.S.; Lim, J.K.; Yang, J.W. Enhancing lipid productivity of Chlorella vulgaris using oxidative stress by $\mathrm{TiO}_{2}$ nanoparticles. Korean J. Chem. Eng. 2014, 31, 861-867.

75. Gong, N.; Shao, K.; Feng, W.; Lin, Z.; Liang, C.; Sun, Y. Biotoxicity of nickel oxide nanoparticles and bio-remediation by microalgae Chlorella vulgaris. Chemosphere 2011, 83, 510-516.

76. Polonini, H.C.; Brandao, H.M.; Raposo, N.R.B.; Brandao, M.A.F.; Mouton, L.; Coute, A.; Yepremian, C.; Sivry, Y.; Brayner, R. Size-dependent ecotoxicity of barium titanate particles: The case of Chlorella vulgaris green algae. Ecotoxicology 2015, 24, 938-948.

77. Ksiazyk, M.; Asztemborska, M.; Steborowski, R.; Bystrzejewska-Piotrowska, G. Toxic effect of silver and platinum nanoparticles toward the freshwater microalga Pseudokirchneriella subcapitata. Bull. Environ. Contam. Toxicol. 2015, 94, 554-558.

78. Blaby-Haas, C.E.; Merchant, S.S. The ins and outs of algal metal transport. Biochim. Biophys. Acta 2012, 1823, 1531-1552.

79. Cassier-Chauvat, C.; Chauvat, F. Responses to oxidative and heavy metal stresses in cyanobacteria: Recent advances. Int. J. Mol. Sci. 2015, 16, 871-886.

80. Perales-Vela, H.V.; Pena-Castro, J.M.; Canizares-Villanueva, R.O. Heavy metal detoxification in eukaryotic microalgae. Chemosphere 2006, 64, 1-10.

81. Sears, M.E. Chelation: Harnessing and enhancing heavy metal detoxification-A review. Sci. World J. 2013, doi:10.1155/2013/219840.

82. Nakanishi, K.; Deuchi, K. Culture of a high-chlorophyll-producing and halotolerant Chlorella vulgaris. J. Biosci. Bioeng. 2014, 117, 617-619.

83. Guesmi, A.; Ladhari, N.; Hamadi, N.B.; Msaddek, M.; Sakli, F. First application of chlorophyll- $a$ as biomordant: Sonicator dyeing of wool with betanin dye. J. Clean. Prod. 2013, 39, 97-104.

84. Park, S.J.; Park, Y.M. Eco-dyeing and antimicrobial properties of chlorophyllin copper complex extracted from Sasa veitchii. Fibers Polym. 2010, 11, 357-362.

85. Kupper, H.; Kupper, F.; Spiller, M. Environmental relevance of heavy metal-substituted chlorophylls using the example of water plants. J. Exp. Bot. 1996, 47, 259-266.

86. Droupadi, P.R.; Krishnan, V. An efficient method of preparation of pheophytin $a$-Divalent metal pheophytinates. Proc. Indian Acad. Sci. 1984, 93, 117-124.

87. Karcz, D.; Boroń, B.; Matwijczuk, A.; Furso, J.; Staroń, J.; Ratuszna, A.; Fiedor, L. Lessons from chlorophylls: Modifications of porphyrinoids towards optimized solar energy conversion. Molecules 2014, 19, 15938-15954. 
88. Moreira, L.M.; Lima, A.; Soares, R.R.S.; Batistela, V.R.; Gerola, A.P.; Hioka, N.; Bonacin, J.A.; Severino, D.; Baptista, M.S.; da Hora Machado, A.E.; et al. Metallochlorophylls of magnesium, copper and zinc: Evaluation of the influence of the first coordination sphere on their solvatochromism and aggregation properties. J. Braz. Chem. Soc. 2009, 20, 1653-1658.

89. Petrovic, J.; Nikolic, G.; Markovic, D. In vitro complexes of copper and zinc with chlorophyll. J. Serb. Chem. Soc. 2006, 71, 501-512.

90. Ngo, T.; Zhao, Y. Formation of zinc-chlorophyll-derivative complexes in thermally processed green pears (Pyruscommunis L.). J. Food Sci. 2007, 72, 397-404.

91. Takaichi, S. Carotenoids in algae: Distributions, biosyntheses and functions. Mar. Drugs 2011, 9 , 1101-1118.

92. Shukla, M.K.; Tripathi, R.D.; Sharma, N.; Dwivedi, S.; Mishra, S.; Singh, R.; Shukla, O.P.; Rai, U.N. Responses of cyanobacterium Anabaena doliolum during nickel stress. J. Environ. Biol. 2009, 30, 871-876.

93. Basaca-Loya, G.A.; Valdez, M.A.; Enriquez-Guevara, E.A.; Gutierrez-Millan, L.E.; Burboa, M.G. Extraction and purification of B-phycoerythrin from the red microalga Rhodosorus marinus. Cienc. Mar. 2009, 35, 359-368.

94. Mishra, S.K.; Shrivastav, A.; Maurya, R.R.; Patidar, S.K.; Haldar, S.; Mishra, S. Effect of light quality on the C-phycoerythrin production in marine cyanobacteria Pseudanabaena sp. isolated from Gujarat coast, India. Protein Expr. Purif. 2012, 81, 5-10.

95. Mortensen, A. Carotenoids and other pigments as natural colorants. Pure Appl. Chem. 2006, 8, 1477-1491.

96. Stahl, W.; Sies, H. Bioactivity and protective effects of natural carotenoids. Biochim. Biophys. Acta 2005, 1740, 101-107.

97. Kuddus, M.; Singh, P.; Thomas, G.; Al-Hazimi, A. Recent developments in production and biotechnological applications of c-phycocyanin. Biomed Res. Int. 2013, doi:10.1155/2013/742859.

98. Ratha, S.K.; Prasanna, R.; Gupta, V.; Dhar, D.W.; Saxena, A.K. Bioprospecting and indexing the microalgal diversity of different ecological habitats of India. World J. Microbiol. Biotechnol. 2012, $28,1657-1667$.

99. Kosakowska, A.; Lewandowska, J.; Ston, J.; Burkiewicz, K. Qualitative and quantitative composition of pigments in Phaeodactylum tricornutum (Bacillariophyceae) stressed by iron. BioMetals 2004, 17, 45-52.

100. Zapata, M.; Fraga, S.; Rodriguez, F.; Garrido, J.L. Pigment-based chloroplast types in dinoflagellates. Mar. Ecol. Prog. Ser. 2012, 465, 33-52.

101. Mohr, R.; Voß, B.; Schliep, M.; Kurz, T.; Maldener, I.; Adams, D.G.; Larkum, A.D.W.; Chen, M.; Hess, W.R. A new chlorophyll $d$-containing cyanobacterium: Evidence for niche adaptation in the genus Acaryochloris. ISME J. 2010, 4, 1456-1469.

102. Chen, M.; Li, Y.; Birch, D.; Willows, R.D. A cyanobacterium that contains chlorophyll $f-\mathrm{A}$ red-absorbing photopigment. FEBS Lett. 2012, 586, 3249-3254.

103. Garbayo, I.; Cuaresma, M.; Vilchez, C.; Vega, J.M. Effect of abiotic stress on the production of lutein and $\beta$-carotene by Chlamydomonas acidophila. Process Biochem. 2008, 43, 1158-1161. 
104. Garbayo, I.; Torronteras, R.; Forjan, E.; Cuaresma, M.; Casal, C.; Mogedas, B.; Ruiz-Dominguez, M.C.; Marquez, C.; Vaquero, I.; Fuentes-Cordero, J.L.; et al. Identification and physiological aspects of a novel carotenoid-enriched, metal-resistant microalga isolated from an acidic river in Huelva (Spain). J. Phycol. 2012, 48, 607-614.

105. Mojaat, M.; Pruvost, J.; Foucault, A.; Legrand, J. Effect of organic carbon sources and $\mathrm{Fe}^{2+}$ ions on growth and $\beta$-carotene accumulation by Dunaliella salina. Biochem. Eng. J. 2008, 39, 177-184.

106. Bhattacharya, P.; Pal, R. Scope of phycoremediation of Arsenic using Phormidium tenue with special reference to modulation in cellular biochemistry. J. Algal Biomass Util. 2012, 3, 1-8.

107. Arunakumara, K.K.I.U.; Xuecheng, Z. Effects of heavy metals $\left(\mathrm{Pb}^{2+}\right.$ and $\left.\mathrm{Cd}^{2+}\right)$ on the ultrastructure, growth and pigment contents of the unicellular cyanobacterium Synechocystis sp. PCC 6803. Chin. J. Oceanol. Limnol. 2009, 27, 383-388.

108. Arunakumara, K.K.I.U.; Xuecheng, Z.; Xiaojin, S. Bioaccumulation of $\mathrm{Pb}^{2+}$ and its effects on growth, morphology and pigment contents of Spirulina (Arthrospira) platensis. J. Ocean Univ. Chin. 2008, 7, 397-403.

109. Shanab, S.; Essa, A.; Shalaby, E. Bioremoval capacity of three heavy metals by some microalgae species (Egyptian Isolates). Plant Signal. Behav. 2012, 7, 1-8.

110. Yang, F.; Wong, K.H.; Yang, Y.; Li, X.; Jiang, J.; Zheng, W.; Wu, H.; Chen, T. Purification and in vitro antioxidant activities of tellurium-containing phycobiliproteins from tellurium-enriched Spirulina platensis. Drug Des. Dev. Ther. 2014, 8, 1789-1800.

111. Hu, Q.; Sommerfeld, M.; Jarvis, E.; Ghirardi, M.; Posewitz, M.; Seibert, M.; Darzins, A. Microalgal triacylglycerols as feedstocks for biofuel production: Perspectives and advances. Plant J. 2008, 54, 621-639.

112. Luo, X.; Su, P.; Zhang, W. Advances in microalgae-derived phytosterols for functional food and pharmaceutical applications. Mar. Drugs 2015, 13, 4231-4254.

113. Arakaki, A.; Iwama, D.; Liang, Y.; Murakami, N.; Ishikura, M.; Tanaka, T.; Matsunaga, T. Glycosylceramides from marine green microalga Tetraselmis sp. Phytochemistry 2013, 85, $107-114$.

114. Yilancioglu, K.; Cokol, M.; Pastirmaci, I.; Erman, B.; Cetiner, S. Oxidative stress is a mediator for increased lipid accumulation in a newly isolated Dunaliella salina strain. PLoS ONE 2014, 9, e91957.

115. Yang, J.S.; Cao, J.; Xing, G.L.; Yuan, H.L. Lipid production combined with biosorption and bioaccumulation of cadmium, copper, manganese and zinc by oleaginous microalgae Chlorella minutissima UTEX2341. Bioresour. Technol. 2015, 175, 537-544.

116. Rocchetta, I.; Mazzuca, M.; Conforti, V.; Ruiz, L.; Balzaretti, V.; Molina, M.C.R. Effect of chromium on the fatty acid composition of two strains of Euglena gracilis. Environ. Pollut. 2006, $141,353-358$.

117. Sun, J.; Cheng, J.; Yang, Z.; Li, K.; Zhou, J.; Cen, K. Microstructures and functional groups of Nannochloropsis sp. cells with arsenic adsorption and lipid accumulation. Bioresour. Technol. 2015, 194, 305-311. 
118. Mohammady, N.G.-E.D.; Fathy, A.A. Humic acid mitigates viability reduction, lipids and fatty acids of Dunaliella salina and Nannochloropsis salina grown under nickel stress. Int. J. Bot. 2007, 3, 64-70.

119. Pinzi, S.; Rounce, P.; Herreros, J.M.; Tsolakis, A.; Dorado, M.P. The effect of biodiesel fatty acid composition on combustion and diesel engine exhaust emissions. Fuel 2013, 104, 170-182.

120. Islam, M.A.; Magnusson, M.; Brown, R.J.; Ayoko, G.A.; Nabi, M.N.; Heimann, K. Microalgal species selection for biodiesel production based on fuel properties derived from fatty acid profiles. Energies 2013, 6, 5676-5702.

121. Stansell, G.R.; Gray, V.M.; Sym, S.D. Microalgal fatty acid composition: Implications for biodiesel quality. J. Appl. Phycol. 2012, 24, 791-801.

122. Komprda, T. Eicosapentaenoic and docosahexaenoic acids as inflammation-modulating and lipid homeostasis influencing nutraceuticals: A review. J. Funct. Foods 2012, 4, 25-38.

123. Wang, M.; Kuo-Dahab, W.C.; Dolan, S.; Park, C. Kinetics of nutrient removal and expression of extracellular polymeric substances of the microalgae, Chlorella sp. and Micractinium sp., in wastewater treatment. Bioresour. Technol. 2014, 154, 131-137.

124. Villay, A.; Laroche, C.; Roriz, D.; Alaoui, H.E.; Delbac, F.; Michaud, P. Optimisation of culture parameters for exopolysaccharides production by the microalga Rhodella violacea. Bioresour. Technol. 2013, 146, 732-735.

125. Mishra, A.; Jha, B. Isolation and characterization of extracellular polymeric substances from micro-algae Dunaliella salina under salt stress. Bioresour. Technol. 2009, 100, 3382-3386.

126. Penna, A.; Berluti, S.; Penna, N.; Magnani, M. Influence of nutrient ratios on the in vitro extracellular polysaccharide production by marine diatoms from the Adriatic Sea. J. Plankton Res. 1999, 21, 1681-1690.

127. Mota, R.; Guimaraes, R.; Buttel, Z.; Rossi, F.; Colica, G.; Silva, C.J.; Santos, C.; Gales, L.; Zille, A.; de Philippis, R.; et al. Production and characterization of extracellular carbohydrate polymer from Cyanothece sp. CCY 0110. Carbohydr. Polym. 2013, 92, 1408-1415.

128. Bafana, A. Characterization and optimization of production of exopolysaccharide from Chlamydomonas reinhardtii. Carbohydr. Polym. 2013, 95, 746-752.

129. Pereira, S.; Zille, A.; Micheletti, E.; Moradas-Ferreira, P.; de Philippis, R. ; Tamagnini, P. Complexity of cyanobacterial exopolysaccharides: Composition, structures, inducing factors and putative genes involved in their biosynthesis and assembly. FEMS Microbiol. Rev 2009, 33, 917-941.

130. Raposo, M.F.J.; de Morais, R.M.S.C.; Bernardo de Morais, A.M.M. Bioactivity and applications of sulphated polysaccharides from marine microalgae. Mar. Drugs 2013, 11, 233-252.

131. Kiran, B.; Thanasekaran, K. Metal tolerance of an indigenous cyanobacterial strain, Lyngbya putealis. Int. Biodeterior. Biodegradation 2011, 65, 1128-1132.

132. Miao, A.J.; Schwehr, K.A.; Xu, C.; Zhang, S.J.; Luo, Z.; Quigg, A.; Santschi, P.H. The algal toxicity of silver engineered nanoparticles and detoxification by exopolymeric substances. Environ. Pollut. 2009, 157, 3034-3041.

133. Zhang, S.J.; Jiang, Y.; Chen, C.S.; Creeley, D.; Schwehr, K.A.; Quigg, A.; Chin, W.C.; Santschi, P.H. Ameliorating effects of extracellular polymeric substances excreted by Thalassiosira pseudonana on algal toxicity of CdSe quantum dots. Aquat. Toxicol. 2013, 126, 214-223. 
134. Goo, B.G.; Baek, G.; Choi, D.J.; Park, Y.I.; Synytsya, A.; Bleha, R.; Seong, D.H.; Lee, C.G.; Park, J.K. Characterization of a renewable extracellular polysaccharide from defatted microalgae Dunaliella tertiolecta. Bioresour. Technol. 2013, 129, 343-350.

135. Ahner, B.A.; Price, N.M.; Morel, F.M.M. Phytochelatin production by marine phytoplankton at low free metal ion concentrations: Laboratory studies and field data from Massachusetts Bay. Proc. Natl. Acad. Sci. USA 1994, 91, 8433-8436.

136. Faucheur, L.S.; Behra, R.; Sigg, L. Phytochelatin induction, cadmium accumulation, and algal sensitivity to free cadmium ion in Scenedesmus vacuolatus. Environ. Toxicol. Chem. 2005, 24, 1731-1737.

137. Kawakami, S.K.; Gledhill, M.; Achterberg, E.P. Effects of metal combinations on the production of phytochelatins and glutathione by the marine diatom Phaeodactylum tricornutum. BioMetals 2006, 19, 51-60.

138. Morelli, E.; Scarano, G. Synthesis and stability of phytochelatins induced by cadmium and lead in the marine diatom Phaeodactylum tricornutum. Mar. Environ. Res. 2001, 52, 383-395.

139. Morelli, E.; Scarano, G. Copper-induced changes of non-protein thiols and antioxidant enzymes in the marine microalga Phaeodactylum tricornutum. Plant Sci. 2004, 167, 289-296.

140. Tukaj, Z.; Bascik-Remisiewicz, A.; Skowronski, T.; Tukaj, C. Cadmium effect on the growth, photosynthesis, ultrastructure and phytochelatin content of green microalga Scenedesmus armatus: A study at low and elevated $\mathrm{CO}_{2}$ concentration. Environ. Exp. Bot. 2007, 60, 291-299.

141. Pawlik-Skowronska, B.; Pirszel, J.; Kalinowska, R.; Skowronski, T. Arsenic availability, toxicity and direct role of GSH and phytochelatins in As detoxification in the green alga Stichococcus bacillaris. Aquat. Toxicol. 2004, 70, 201-212.

142. Volland, S.; Schaumloffer, D.; Dobritzsch, D.; Krauss, G.J.; Lutz-Meindl, U. Identification of phytochelatins in the cadmium-stressed conjugating green alga Micrasterias denticulata. Chemosphere 2013, 91, 448-454.

143. Bhargava, P.; Srivastava, A.K.; Urmil, S.; Rai, L.C. Phytochelatin plays a role in UV-B tolerance in $\mathrm{N}_{2}$-fixing cyanobacterium Anabaena doliolum. J. Plant Physiol. 2005, 162, 1220-1225.

144. Brautigam, A.; Bomke, S.; Pfeifer, T.; Karst, U.; Krauss, G.J.; Wesenberg, D. Quantification of phytochelatins in Chlamydomonas reinhardtii using ferrocene-based derivatization. Metallomics 2010, 2, 565-570.

145. Adam, V.; Zehnalek, J.; Petrlova, J.; Potesil, D.; Sures, B.; Trnkova, L.; Jelen, F.; Vitecek, J.; Kizek, R. Phytochelatin modified electrode surface as a sensitive heavy-metal ion biosensor. Sensors 2005, 5, 70-84.

146. Politi, J.; Spadavecchia, J.; Iodice, M.; de Stefano, L. Oligopeptide-Heavy metal interaction monitoring by hybrid gold nanoparticle based assay. Analyst 2015, 140, 149.

147. Thomas, J.; Ross, C.W.; Chastain, C.J.; Koomanoff, N.; Hendrix, J.E.; Volkenburgh, E.V. Cytokinin-induced wall extensibility in excised cotyledons of radish and cucumber. Plant Physiol. 1981, 68, 107-110.

148. Wareing, P.F.; Bradbeer, J.W. Abscisic acid as a natural growth regulator (and discussion). Philos. Trans. R. Soc. Lond. B 1978, 284, 483-498.

149. Prusty, R.; Grisafi, P.; Fink, G.R. The plant hormone indoleacetic acid induces invasive growth in Saccharomyces cerevisiae. PNAS 2004, 101, 4153-4157. 
150. Rattan, S.I.S.; Sodagam, L. Gerontomodulatory and youth-preserving effects of zeatin on human skin fibroblasts undergoing aging in vitro. Rejuvenation Res. 2005, 8, 46-57.

151. Liu, X.; Berezniak, T.; Panek, J.J.; Jezierska-Mazzarello, A. Theoretical study of zeatin-A plant hormone and potential drug for neural diseases - On the basis of DFT, MP2 and target docking. Chem. Phys. Lett. 2013, 557, 140-144.

152. Kawano, T. Possible use of indole-3-acetic acid and its antagonist tryptophan betaine in controlled killing of horseradish peroxidase-labeled human cells. Med. Hypotheses 2003, 60, 664-666.

153. Lu, Y.; Xu, J. Phytohormones in microalgae: A new opportunity for microalgal biotechnology? Trends Plant Sci. 2015, 20, 273-282.

154. Bajguz, A. Suppression of Chlorella vulgaris growth by cadmium, lead, and copper stress and its restoration by endogenous brassinolide. Arch. Environ. Contam. Toxicol. 2011, 60, 406-416.

155. Wang, Y.; Wang, S.; Xu, P.; Liu, C.; Liu, M.; Wang, Y.; Wang, C.; Zhang, C.; Ge, Y. Review of arsenic speciation, toxicity and metabolism in microalgae. Rev. Environ. Sci. Biotechnol. 2015, doi:10.1007/s11157-015-9371-9.

156. Yan, C.; Wang, Z.; Luo, Z. Arsenic Efflux from Microcystis aeruginosa under different phosphate regimes. PLoS ONE 2014, 9, e116099.

157. Xue, X.M.; Raber, G.; Foster, S.; Chen, S.C.; Francesconi, K.A.; Zhu, Y.G. Biosynthesis of arsenolipids by the cyanobacterium Synechocystis sp. PCC 6803. Environ. Chem. 2014, 11, 506-513.

158. Wang, Z.; Luo, Z.; Yan, C. Accumulation, transformation, and release of inorganic arsenic by the freshwater cyanobacterium Microcystis aeruginosa. Environ. Sci. Pollut. Res. 2013, 20, 7286-7295.

159. Dembitsky, V.M.; Levitsky, D.O. Arsenolipids. Prog. Lipid Res. 2004, 43, 403-448.

160. Miyashita, S.I.; Fujiwara, S.; Tsuzuki, M.; Kaise, T. Rapid biotransformation of arsenate into oxo-arsenosugars by a freshwater unicellular green alga, Chlamydomonas reinhardtii. Biosci. Biotechnol. Biochem. 2011, 75, 522-530.

161. Miyashita, S.I.; Fujiwara, S.; Tsuzuki, M.; Kaise, T. Cyanobacteria produce arsenosugars. Environ. Chem. 2012, 9, 474-484.

162. Duncan, E.G.; Maher, W.A.; Foster, S.D.; Krikowa, F. The influence of arsenate and phosphate exposure on arsenic uptake, metabolism and species formation in the marine phytoplankton Dunaliella tertiolecta. Mar. Chem. 2013, 157, 78-85.

163. Foster, S.; Thomson, D.; Maher, W. Uptake and metabolism of arsenate by axenic cultures of the microalgae Dunaliella tertiolecta and Phaeodactylum tricornutum. Mar. Chem. 2008, 108, $172-183$.

164. Chen, B.; Liu, Q.; Popowich, A.; Shen, S.; Yan, X.; Zhang, Q.; Li, X.F.; Weinfeld, M.; Cullen, W.R.; Le, X.C. Therapeutic and analytical applications of arsenic binding to proteins. Metallomics 2015, 7, 39.

165. Ju-Nam, Y.; Lead, J.R. Manufactured nanoparticles: An overview of their chemistry, interactions and potential environmental implications. Sci. Total Environ. 2008, 400, 396-414.

166. Schrofel, A.; Kratosova, G.; Safarik, I.; Safarikova, M.; Raska, I.; Shor, L.M. Applications of biosynthesized metallic nanoparticles_A review. Acta Biomater. 2014, 10, 4023-4042. 
167. Tavakoli, A.; Sohrabi, M.; Kargari, A. A Review of methods for synthesis of nanostructured metals with emphasis on iron compounds. Chem. Pap. 2007, 61, 151-170.

168. Hulkoti, N.I.; Taranath, T.C. Biosynthesis of nanoparticles using microbes-A review. Colloids Surf. B Biointerfaces 2014, 121, 474-483.

169. Płaza, G.A.; Chojniak, J.; Banat, I.M. Biosurfactant mediated biosynthesis of selected metallic nanoparticles. Int. J. Mol. Sci. 2014, 15, 13720-13737.

170. Luangpipat, T.; Beattie, I.R.; Chisti, Y.; Haverkamp, R.G. Gold nanoparticles produced in a microalga. J. Nanopart. Res. 2011, 13, 6439-6445.

171. Feurtet-Mazel, A.; Mornet, S.; Charron, L.; Mesmer-Dudons, N.; Maury-Brachet, R.; Baudrimont, M. Biosynthesis of gold nanoparticles by the living freshwater diatom Eolimna minima, a species developed in river biofilms. Environ. Sci. Pollut. Res. 2015, doi:10.1007/s11356-015-4139-x.

172. Kadukova, J.; Velgosova, O.; Mrazikova, A.; Marcincakova, R. The effect of culture age and initial silver concentration on biosynthesis of Ag nanoparticles. Nova Biotechnol. Chim. 2014, 13, 28-37.

173. Patel, V.; Berthold, D.; Puranik, P.; Gantar, M. Screening of cyanobacteria and microalgae for their ability to synthesize silver nanoparticles with antibacterial activity. Biotechnol. Rep. 2014, 20, 7286-7295.

174. Jena, J.; Pradhan, N.; Nayak, R.R.; Dash, B.P.; Sukla, L.B.; Panda, P.K.; Mishra, B.K. Microalga Scenedesmus sp.: A potential low-cost green machine for silver nanoparticle synthesis. J. Microbiol. Biotechnol. 2014, 24, 522-533.

175. Eroglu, E.; Chen, X.; Bradshaw, M.; Agarwal, V.; Zou, J.; Stewart, S.G.; Duan, X.; Lamb, R.N.; Smith, S.M.; Raston, C.L.; et al. Biogenic production of palladium nanocrystals using microalgae and their immobilization on chitosan nanofibers for catalytic applications. RSC $A d v$. 2013, 3, 1009.

176. Lengke, M.F.; Fleet, M.E.; Southam, G. Synthesis of palladium nanoparticles by reaction of filamentous cyanobacterial biomass with a palladium(II) chloride complex. Langmuir 2007, 23, 8982-8987.

177. Jena, J.; Pradhan, N.; Aishvarya, V.; Nayak, R.R.; Dash, B.P.; Sukla, L.B.; Panda, P.K.; Mishra, B.K. Biological sequestration and retention of cadmium as CdS nanoparticles by the microalga Scenedesmus-24. J. Appl. Phycol. 2014, doi:10.1007/s10811-014-0499-8.

178. Santomauro, G.; Srot, V.; Bussmann, B.; van Aken, P.A.; Brümmer, F.; Strunk, H.; Bill, J. Biomineralization of zinc-phosphate-based nano needles by living microalgae. J. Biomater. Nanobiotechnol. 2012, 3, 362-370.

179. Schulze, H.; Brand, J.J. Lead toxicity and phosphate deficiency in Chlamydomonas. Plant Physiol. 1978, 62, 727-730.

180. Mera, R.; Torres, E.; Abalde, J. Sulphate, more than a nutrient, protects the microalga Chlamydomonas moewusii from cadmium toxicity. Aquat. Toxicol. 2014, 148, 92-103.

181. Edwards, C.D.; Beatty, J.C.; Loiselle, J.B.R.; Vlassov, K.A.; Lefebvre, D.D. Aerobic transformation of cadmium through metal sulfide biosynthesis in photosynthetic microorganisms. BMC Microbiol. 2013, 13, 161.

182. Liu, J.; Sun, Z.; Lavoie, M.; Fan, X.; Bai, X.; Qian, H. Ammonium reduces chromium toxicity in the freshwater alga Chlorella vulgaris. Appl. Microbiol. Biotechnol. 2015, 99, 3249-3258. 
183. Deleebeeck, N.M.E.; de Schamphelaere, K.A.C.; Janssen, C.R. Effects of $\mathrm{Mg}^{2+}$ and $\mathrm{H}^{+}$on the toxicity of $\mathrm{Ni}^{2+}$ to the unicellular green alga Pseudokirchneriella subcapitata: Model development and validation with surface waters. Sci. Total Environ. 2009, 407, 1901-1914.

184. Franklin, N.M.; Stauber, J.L.; Markich, S.J.; Lim, R.P. pH-dependent toxicity of copper and uranium to a tropical freshwater alga (Chlorella sp.). Aquat. Toxicol. 2000, 48, 275-289.

185. Volland, S.; Bayer, E.; Baumgartner, V.; Andosch, A.; Lutz, C.; Sima, E.; Lutz-Meindl, U. Rescue of heavy metal effects on cell physiology of the algal model system Micrasterias by divalent ions. J. Plant Physiol. 2014, 171, 154-163.

186. Cheloni, G.; Cosio, C.; Slaveykova, V.I. Antagonistic and synergistic effects of light irradiation on the effects of copper on Chlamydomonas reinhardtii. Aquat. Toxicol. 2014, 155, 275-282.

187. Piotrowska-Niczyporuk, A.; Bajguz, A.; Zambrzycka, E.; Godlewska-Zylkiewicz, B. Phytohormones as regulators of heavy metal biosorption and toxicity in green alga Chlorella vulgaris (Chlorophyceae). Plant Physiol. Biochem. 2012, 52, 52-65.

188. Ma, M.; Zhu, W.; Wang, Z.; Witkamp, G.J. Accumulation, assimilation and growth inhibition of copper on freshwater alga (Scenedesmus subspicatus $86.81 \mathrm{SAG}$ ) in the presence of EDTA and fulvic acid. Aquat. Toxicol. 2003, 63, 221-228.

189. Hao, S.; Xiaorong, W.; Liansheng, W.; Lemei, D.; Zhong, L.; Yijun, C. Bioconcentration of rare earth elements lanthanum, gadolinium and yttrium in algae (Chlorella Vulgarize Beijerinck): Influence of chemical species. Chemosphere 1997, 34, 1753-1760.

190. Errecalde, O.; Seidl, M.; Campbell, P.G.C. Influence of a low molecular weight metabolite (citrate) on the toxicity of cadmium and zinc to the unicellular green alga Selenastrum capricornutum: An exception to the free-ion model. Water Res. 1998, 32, 419-429.

191. Gerringa, L.J.A.; de Baar, H.J.W.; Timmermans, K.R. A comparison of iron limitation of phytoplankton in natural oceanic waters and laboratory media conditioned with EDTA. Mar. Chem. 2000, 68, 335-346.

192. Lewin, J.; Chen, C.H. Available iron: A limiting factor for marine phytoplankton. Limnol. Oceanogr. 1971, 16, 670-675.

193. Botebol, H.; Sutak, R.; Scheiber, I.F.; Blaiseau, P.L.; Bouget, F.Y.; Camadro, J.M.; Lesuisse, E. Different iron sources to study the physiology and biochemistry of iron metabolism in marine micro-algae. Biometals 2014, 27, 75-88.

194. Kean, M.A.; Brons Delgado, E.; Mensink, B.P.; Bugter, M.H.J. Iron chelating agents and their effects on the growth of Pseudokirchneriella subcapitata, Chlorella vulgaris, Phaeodactylum tricornutum and Spirulina platensis in comparison to Fe-EDTA. J. Algal Biomass Util. 2015, 6, 56-73.

195. Koukal, B.; Gueguen, C.; Pardos, M.; Dominik, J. Influence of humic substances on the toxic effects of cadmium and zinc to the green alga Pseudokirchneriella subcapitata. Chemosphere 2003, 53, 953-961.

196. Kaladharan, P.; Leela Bhai, K.S. Effect of humic acids on mercury toxicity to marine algae. Fish. Technol. 2007, 44, 93-98.

197. Tang, Y.; Li, S.; Lu, Y.; Li, Q.; Yu, S. The Influence of humic acid on the toxicity of nano-ZnO and $\mathrm{Zn}^{2+}$ to the Anabaena sp. Environ. Toxicol. 2014, doi:10.1002/tox.21964. 
198. Sanchez-Marin, P.; Beiras, R. Adsorption of different types of dissolved organic matter to marine phytoplankton and implications for phytoplankton growth and $\mathrm{Pb}$ bioavailability. J. Plankton Res. 2011, 33, 1396-1409.

199. Lamelas, C.; Wilkinson, K.J.; Slaveykova, V.I. Influence of the composition of natural organic matter on Pb bioavailability to microalgae. Environ. Sci. Technol. 2005, 39, 6109-6116.

200. Sun, B.; Tanji, Y.; Unno, H. Influences of iron and humic acid on the growth of the cyanobacterium Anabaena circinalis. Biochem. Eng. J. 2005, 24, 195-201.

201. Worms, I.A.M.; Adenmatten, D.; Mieville, P.; Traber, J.; Slaveykova, V.I. Photo-transformation of pedogenic humic acid and consequences for $\mathrm{Cd}(\mathrm{II}), \mathrm{Cu}(\mathrm{II})$ and $\mathrm{Pb}(\mathrm{II})$ speciation and bioavailability to green microalga. Chemosphere 2015, 138, 908-915.

202. Parent, L.; Twiss, M.R.; Campbell, P.G.C. Influences of natural dissolved organic matter on the interaction of aluminum with the microalga Chlorella: A Test of the free-ion model of trace metal toxicity. Environ. Sci. Technol. 1996, 30, 1713-1720.

203. Tang, Y.; Tian, J.; Li, S.; Xue, C.; Xue, Z.; Yin, D.; Yu, S. Combined effects of graphene oxide and $\mathrm{Cd}$ on the photosynthetic capacity and survival of Microcystis aeruginosa. Sci. Total Environ. 2015, 532, 154-161.

204. Yang, W.W.; Miao, A.J.; Yang, L.Y. $\mathrm{Cd}^{2+}$ Toxicity to a green alga Chlamydomonas reinhardtii as influenced by its adsorption on $\mathrm{TiO}_{2}$ engineered nanoparticles. PLoS ONE 2012, 7, e32300.

205. Worms, I.A.M.; Boltzman, J.; Garcia, M.; Slaveykova, V.I. Cell-wall-dependent effect of carboxyl-CdSe/ZnS quantum dots on lead and copper availability to green microalgae. Environ. Pollut. 2012, 167, 27-33.

206. Szejtli, J. Comprehensive Supramolecular Chemistry; Pergamon Press: Oxford, UK, 1996; Volume 3.

207. Bender, M.L.; Momiyama, M. Cyclodextrin Chemistry; Springer: Berlin, Germany, 1978.

208. Loftsson, T.; Brewster, M.E. Pharmaceutical applications of cyclodextrins. 1. Drug solubilization and stabilization. J. Pharm. Sci. 1996, 85, 1017-1025.

209. Zia, V.; Rajewski, R.A.; Stella, V.J. Effect of cyclodextrin charge on complexation of neutral and charged substrates: Comparison of (SBE) $7 \mathrm{M}-\beta-\mathrm{CD}$ to HP- $\beta$-CD. Pharm. Res. 2001, 18, 667-673.

210. Singh, M.; Sharma, R.; Banerjee, U.C. Biotechnological applications of cyclodextrins. Biotechnol. Adv. 2002, 20, 341-359.

211. Challa, R.; Ahuja, A.; Ali, J.; Khar, R.K. Cyclodextrins in drug delivery: An updated review. AAPS PharmSciTech 2005, 6, 329-357.

212. Bellia, F.; la Mendola, D.; Pedone, C.; Rizzarelli, E.; Saviano, M.; Vecchio, G. Selectively functionalized cyclodextrins and their metal complexes. Chem. Soc. Rev. 2009, 38, 2756-2781.

213. Meng, X.; Pan, Q.; Liu, Y. Preparation and properties of phytosterols with hydroxypropyl $\beta$-cyclodextrin inclusion complexes. Eur. Food Res. Technol. 2012, 235, 1039-1047.

214. Yuan, C.; Jin, Z.; Xu, X. Inclusion complex of astaxanthin with hydroxypropyl- $\beta$-cyclodextrin: UV, FTIR, ${ }^{1}$ H NMR and molecular modeling studies. Carbohydr. Polym. 2012, 89, 492-496.

215. Hoffman, D.R.; Anderson, P.P.; Schubert, C.M.; Gault, M.B.; Blanford, W.J.; Sandrin, T.R. Carboxymethyl- $\beta$-cyclodextrin mitigates toxicity of cadmium, cobalt and copper during naphthalene biodegradation. Bioresour. Technol. 2010, 101, 2672-2677. 
216. Bi Fai, P.; Grant, A.; Reid, B.J. Compatibility of hydroxypropyl- $\beta$-cyclodextrin with algal toxicity bioassays. Environ. Pollut. 2009, 157, 135-140.

217. Gutsche, C. Calixarenes, Monographs in Supramolecular Chemistry; Stoddart, J., Ed.; The Royal Society of Chemisfry: Cambridge, UK, 1989.

218. Gutsche, C.D.; Iqbal, M. p-tert-Butylcalix[4]arene. Org. Synth. 1990, 68, 234-237.

219. Gutsche, C.D.; Dhawan, B.; Leonis, M.; Stewart, D. p-tert-Butylcalix[6]arene. Org. Synth. 1990, 68, 238-242.

220. Munch, J.H.; Gutsche, C.D. p-tert-Butylcalix[8]arene. Org. Synth. 1990, 68, 243-245.

221. Cram, D.J.; Cram, J.M. Container Molecules and Their Guests; The Royal Society of Chemistry: Cambridge, UK, 1997.

222. Sliwa, W.; Kozlowski, C. Calixarenes and Resorcinarenes: Synthesis, Properties and Applications; Wiley-VCH: Weinheim, Germany, 2009.

223. Schneider, H.J.; Güttes, D.; Schneider, U. A macrocyclic polyphenolate as receptor analogue for cholin and related ammonium compounds. Angew. Chem. Int. Ed. Engl. 1986, 25, 647-649.

224. Schneider, H.J.; Güttes, D.; Schneider, U. Host-guest complexes with water soluble macrocyclic polyphenolates including induced fit and simple elements of a proton pump. J. Am. Chem. Soc. 1988, 110, 6449-6454.

225. Casnati, A.; Sciotto, D.; Arena, G. Calixarenes 2001; Asfari, Z., Behmer, V., Harrowfield, J., Vicens, J., Eds.; Kluwer Academic Pubhshers: Dordrecht, The Netherlands, 2001; pp. 440-457.

226. Arena, G.; Cali, R.; Lombardo, G.G.; Rizzarelli, E.; Sciotto, D.; Ungaro, R.; Casnati, A. Water soluble calix[4]arenes. A thermodynamic investigation of proton complex formation. Supramol. Chem. 1992, 1, 19-24.

227. Johnson, C.P.; Atwood, J.L.; Steed, J.W.; Bauer, C.B.; Rogers, R.D. Transition metal complexes of $p$-sulfonatocalix[5]arene. Inorg. Chem. 1996, 35, 2602-2610.

228. Gangemi, C.M.A.; Pappalardo, A.; Sfrazzetto, G.T. Applications of supramolecular capsules derived from resorcin[4]arenes, calix[ $n]$ arenes and metallo-ligands: From biology to catalysis. RSC Adv. 2015, 5, 51919-51933.

229. Kobayashi, K.; Tominaga, M.; Asakawa, Y.; Aoyama, Y. Binding of amino acids in water to a highly electron-rich aromatic cavity of pyrogallol or resorcinol cyclic tetramer as $\pi$-base. Tetrahedron Lett. 1993, 34, 5121-5124.

230. Kobayashi, K.; Asakawa, Y.; Aoyama, Y. Complexation of methylammonium salts and sugar-related alcohols with resorcinol cyclic tetramer in water: An implication of the $\mathrm{CH}-\pi$ interaction on polar guest binding. Supramol. Chem. 1993, 2, 133-135.

231. Kobayashi, K.; Asakawa, Y.; Kato, Y.; Aoyama, Y. Complexation of hydrophobic sugars and nucleosides in water with tetrasulfonate derivatives of resorcinol cyclic tetramer having a polyhydroxy aromatic cavity: Importance of guest-host $\mathrm{CH}-\pi$ interaction. J. Am. Chem. Soc. 1992, 114, 10307-10313.

232. Lamartinea, R.; Tsukadab, M.; Wilson, D.; Shirata, A. Antimicrobial activity of calixarenes. C. R. Chim. 2002, 5, 163-169. 
233. Mouradzadegun, A.; Elahi, S.; Abadast, F.; Motamedi, H. A straightforward route for covalently anchored pyridinium salt onto upper rim of $c$-methylcalix[4]resorcinarene with selective antibacterial activity against Gram-positive bacteria. Res. Chem. Intermed. 2015, doi:10.1007/ s11164-015-2104-4.

234. Yoshida, N.; Ikeda, R.; Okuno, T. Identification and characterization of heavy metal-resistant unicellular alga isolated from soil and its potential for phytoremediation. Bioresour. Technol. 2006, 97, 1843-1849.

235. Kalinowska, R.; Pawlik-Skowronska, B. Metal resistance of soil algae (Chlorophyta) occurring in post-flotation $\mathrm{Zn} / \mathrm{Pb}$ - and Cu-tailing ponds. Pol. J. Ecol. 2008, 56, 415-430.

236. Kalinowska, R.; Pawlik-Skowronska, B. Response of two terrestrial green microalgae (Chlorophyta, Trebouxiophyceae) isolated from $\mathrm{Cu}$-rich and unpolluted soils to copper stress. Environ. Pollut. 2010, 158, 2778-2785.

237. Halter, D.; Casiot, C.; Heipieper, H.J.; Plewniak, F.; Marchal, M.; Simon, S.; Arsène-Ploetze, F.; Bertin, P.N. Surface properties and intracellular speciation revealed an original adaptive mechanism to arsenic in the acid mine drainage bio-indicator Euglena mutabilis. Appl. Microbiol. Biotechnol. 2012, 93, 1735-1744.

238. Marva, F.; Garcia-Balboa, C.; Baselga-Cervera, B.; Costas, E. Rapid adaptation of some phytoplankton species to osmium as a result of spontaneous mutations. Ecotoxicology 2014, 23, 213-220.

239. Ipatova, V.I.; Spirkina, N.E.; Dmitrieva, A.G. Resistance of microalgae to colloidal silver nanoparticles. Russ. J. Plant Physiol. 2015, 62, 253-261.

240. Baos, R.; Garcia-Villada, L.; Agrelo, M.; Lopez-Rodas, V.; Hiraldo, F.; Costas, E. Short-term adaptation of microalgae in highly stressful environments: An experimental model analysing the resistance of Scenedesmus intermedius (Chlorophyceae) to the heavy metals mixture from the Aznalcóllar mine spill. Eur. J. Phycol. 2002, 37, 593-600.

241. Fathi, A.A.; Zaki, F.T.; Ibraheim, H.A. Response of tolerant and wild type strains of Chlorella vulgaris to copper with special references to copper uptake system. Protistology 2005, 4, 73-78.

242. Abdel-Raouf, N.; Al-Homaidan, A.A.; Ibraheem, I.B.M. Microalgae and wastewater treatment. Saudi J. Biol. Sci. 2012, 19, 257-275.

243. Kumar, K.S.; Dahms, H.U.; Won, E.J.; Lee, J.S.; Shin, K.H. Microalgae-A promising tool for heavy metal remediation. Ecotoxicol. Environ. Saf. 2015, 113, 329-352.

244. Nikookar, K.; Moradshahi, A.; Hosseini, L. Physiological responses of Dunaliella salina and Dunaliella tertiolecta to copper toxicity. Biomol. Eng. 2005, 22, 141-146.

245. Pistocchi, R.; Guerrini, F.; Balboni, V.; Boni, L. Copper toxicity and carbohydrate production in the microalgae Cylindrotheca fusiformis and Gymnodinium sp. Eur. J. Phycol. 1997, 32, 125-132.

246. Lopez, A.; Rico, M.; Santana-Casiano, J.M.; Gonzalez, A.G.; Gonzalez-Davila, M. Phenolic profile of Dunaliella tertiolecta growing under high levels of copper and iron. Environ. Sci. Pollut. Res. 2015, doi:10.1007/s11356-015-4717-y.

247. Chia, M.A.; Lombardi, A.T.; da Graca Gama Melao, M.; Parrish, C.C. Combined nitrogen limitation and cadmium stress stimulate total carbohydrates, lipids, protein and amino acid accumulation in Chlorella vulgaris (Trebouxiophyceae). Aquat. Toxicol. 2015, 160, 87-95. 
248. Bossuyt, B.T.A.; Janssen, C.R. Long-term acclimation of Pseudokirchneriella subcapitata (Korshikov) Hindak to different copper concentrations: Changes in tolerance and physiology. Aquat. Toxicol. 2004, 68, 61-74.

249. Radzun, K.A.; Wolf, J.; Jakob, G.; Zhang, E.; Stephens, E.; Ross, I.; Hankamer, B. Automated nutrient screening system enables high-throughput optimisation of microalgae production conditions. Biotechnol. Biofuels 2015, 8, 65.

250. Ozkan, A.; Kinney, K.; Katz, L.; Berberoglu, H. Reduction of water and energy requirement of algae cultivation using an algae biofilm photobioreactor. Bioresour. Technol. 2012, 114, 542-548.

251. El-Enany, A.E.; Issa, A.A. Cyanobacteria as a biosorbent of heavy metals in sewage water. Environ. Toxicol. Pharmacol. 2000, 8, 95-101.

252. Harrison, E.Z.; Oakes, S.R.; Hysell, M.; Hay, A. Organic chemicals in sewage sludges. Sci. Total Environ. 2006, 367, 481-497.

253. Mustafa, E.M.; Phang, S.M.; Chu, W.L. Use of an algal consortium of five algae in the treatment of landfill leachate using the high-rate algal pond system. J. Appl. Phycol. 2012, 24, 953-963.

254. Richards, R.G.; Mullins, B.J. Using microalgae for combined lipid production and heavy metal removal from leachate. Ecol. Modell. 2013, 249, 59-67.

255. Napan, K.; Teng, L.; Quinn, J.C.; Wood, B.D. Impact of heavy metals from flue gas integration with microalgae production. Algal Res. 2015, 8, 83-88.

256. Gopalakrishnan, V.; Ramamurthy, D. Dyeing industry effluent system as lipid production medium of Neochloris sp. for biodiesel feedstock preparation. Biomed. Res. Int. 2014, doi:10.1155/ 2014/529560.

257. White, S.; Anandraj, A.; Trois, C. The effect of landfill leachate on hydrogen production in Chlamydomonas reinhardtii as monitored by PAM Fluorometry. Int. J. Hydrog. Energy 2013, 38, 14214-14222.

258. Borowitzka, M.A. Commercial production of microalgae: Ponds, tanks, tubes and fermenters. J. Biotechnol. 1999, 70, 313-321.

259. Moreno-Garrido, I.; Lubian, L.M.; Soares, A.M.V.M. Influence of cellular density on determination of $\mathrm{EC}_{50}$ in microalgal growth inhibition tests. Ecotoxicol. Environ. Saf. 2000, 47, 112-116.

260. Franklin, N.M.; Stauber, J.L.; Apte, S.C.; Lim.; R.P. Effect of initial cell density on the bioavailability and toxicity of copper in microalgal bioassays. Environ. Toxicol. Chem. 2002, 21, $742-751$.

261. Zhang, W.; Tan, N.G.J.; Fu, B.; Li, S.F.Y. Metallomics and NMR-based metabolomics of Chlorella sp. reveal the synergistic role of copper and cadmium in multi-metal toxicity and oxidative stress. Metallomics 2015, doi:10.1039/c4mt00253a.

262. Song, L.; Qin, J.G.; Su, S.; Xu, J.; Clarke, S.; Shan, Y. Micronutrient requirements for growth and hydrocarbon production in the oil producing green alga Botryococcus braunii (Chlorophyta). PLOS ONE 2012, 7, e41459.

263. Liu, Z.Y.; Wang, G.C.; Zhou, B.C. Effect of iron on growth and lipid accumulation in Chlorella vulgaris. Bioresour. Technol. 2008, 99, 4717-4722. 
264. Dou, X.; Lu, X.H.; Lu, M.Z.; Yu, L.S.; Xue, R.; Ji, J.B. The effects of trace elements on the lipid productivity and fatty acid composition of Nannochloropis oculata. J. Renew. Energy 2013, doi:10.1155/2013/671545.

265. Berberoglu, H.; Jay, J.; Pilon, L. Effect of nutrient media on photobiological hydrogen production by Anabaena variabilis ATCC 29413. Int. J. Hydrog. Energy 2008, 33, 1172-1184.

266. Becker, L.J.M.; Meisch, H.U. Effect of vanadate and iron stress on the pigment composition of Chlorella fusca. Z. Naturforsch. 1981, 36, 207-209.

267. Salama, E.S.; Kabra, A.N.; Ji, M.K.; Kim, J.R.; Min, B.; Jeon, B.H. Enhancement of microalgae growth and fatty acid content under the influence of phytohormones. Bioresour. Technol. 2014, 172, 97-103.

268. Josephine, A.; Niveditha, C.; Radhika, A.; Shali, A.B.; Kumar, T.S.; Dharani, G.; Kirubagaran, R. Analytical evaluation of different carbon sources and growth stimulators on the biomass and lipid production of Chlorella vulgaris-Implications for biofuels. Biomass Bioenergy 2015, 75, 170-179.

269. Pradeep, V.; van Ginkel, S.W.; Park, S.; Igou, T.; Yi, C.; Fu, H.; Johnston, R.; Snell, T.; Chen, Y. Use of copper to selectively inhibit Brachionus calyciflorus (Predator) growth in Chlorella kessleri (Prey) mass cultures for algae biodiesel production. Int. J. Mol. Sci. 2015, 16, 20674-20684.

(C) 2015 by the authors; licensee MDPI, Basel, Switzerland. This article is an open access article distributed under the terms and conditions of the Creative Commons Attribution license (http://creativecommons.org/licenses/by/4.0/). 